Article

\title{
Deciphering the Iron Provenance on a Medieval Building Yard: The Case of Bourges Cathedral
}

\author{
Maxime L'Héritier ${ }^{1}$, Philippe Dillmann ${ }^{2, *}$ and Guillaume Sarah ${ }^{3}$ \\ 1 Department of History, Université Paris 8, ARSCAN CNRS UMR 7041, CEDEX 93526 Saint-Denis, France; \\ maxime.1_heritier@univ-paris8.fr \\ 2 LAPA-IRAMAT, NIMBE, CEA, CNRS, Université Paris-Saclay, CEA Saclay, 91191 Gif-sur-Yvette, France \\ 3 IRAMAT-CEB UMR5060, Université d'Orléans, CEDEX 2, 45071 Orléans, France; \\ guillaume.sarah@cnrs-orleans.fr \\ * Correspondence: Philippe.dillmann@cea.fr
}

Received: 28 November 2020; Accepted: 14 December 2020; Published: 16 December 2020

check for updates

\begin{abstract}
This paper presents the provenance study of the iron reinforcements of Bourges Cathedral (13th c.): the links of a $100 \mathrm{~m}$ long iron chain, surrounding the eastern parts of the cathedral at the triforium level and 4.5 to $5 \mathrm{~m}$ long tie-rods consolidating the arches of the inner aisle at the same level. The analytical methodology is based on the determination of trace rare earth elements analyses by LA-ICP-MS in the slag inclusions of the artefacts and in the slag found on candidate production sites combined with statistical approaches. This chemical approach is crossed with archaeological and historical studies on the monument itself and on the production sites. Ninety-nine iron samples were analyzed on the bars and chains and 238 iron slags from 3 presumed areas of supply. For the first time, iron circulation and trade around a single building yard over a time of 30 to 40 years is studied with a precision never obtained before with historical sources. It shows that mainly four different metallurgical districts, local and more distant, supplied the building yard, mostly depending on the construction phases and also on the types of iron armatures needed.
\end{abstract}

Keywords: iron; provenance; Bourges Cathedral; trace elements; LA-ICP-MS

\section{Introduction}

In the past twenty years, several studies have shown that iron was included in the design of many ancient buildings. Particularly, it is now well-known that major gothic churches were armed with tons of chains, tie-rods and cramps of iron at least since the late 12th century [1-4]. These iron armatures were sometimes used as reinforcements in order to consolidate a part of the masonry or the carpentry work, but they were, most of the time, included in the initial design of these monumental structures: to attach stained glass panels, to bind stones and to strengthen walls or arches [2]. Overall, more than 20 tons of iron were used for the construction of Rouen Cathedral [1], maybe up to 40 tons in the Regensburg Cathedral [5], at least 40 tons in Troyes Cathedral and abbey church Saint-Ouen in Rouen [1], 50 tons in Amiens Cathedral [6] and more than one hundred tons in the Popes Palace in Avignon, where iron expenses are up to $12 \%$ of the total building yard [7]. Sometimes, during glazing campaigns for example, several tons of iron were bought by the building yard from smiths or merchants on a single year [8]. How these large quantities of iron were produced and where they came from are two of the many questions that arise regarding the supply of these building yards and more globally regarding the medieval iron market.

In the Middle Ages, historical sources indeed testify that ferrous products could be traded locally or internationally, sometimes according to their quality [9]. In the Chatillonnais (Burgundy), Odette Chapelot [10] discriminates three kinds of provenance areas for iron: international (and notably 
the use of Spanish iron), regional and local, the last two being predominant. Accounting books from Troyes in Champagne seem to share the same pattern. They occasionally mention the purchase of Spanish iron in the late 14th century for the cathedral building yard [1]. However, according to these texts, the main production areas in the 15 th century seem to be the local forêt d'Othe (15 km westwards) and the Reclus abbey (at $75 \mathrm{~km}$ northwards). Yet, historical sources can sometimes be treacherous: it was indeed proven that the iron chains placed in the triforium of the Amiens Cathedral around 1500 which the related texts claimed to be Spanish iron [6] were instead made of blast furnace and finery iron, an ironmaking process unknown in Spain at that time [11].

So far, these written sources were the only mean to trace the provenance of iron but recent archaeometric studies brought new perspectives. As far as provenance studies of iron artefacts are concerned, several approaches were attempted during these last decades. They are all based on the idea that the chemical or isotopic signature of the initial ore remains unchanged in the artefact [12]. Some approaches consider the isotope ratios of some elements that are passing into the metal during the fractionation processes happening during the smelting of the ore (transformation of ore into metal by reduction). This process took place in solid state in ancient metallurgy, using the so called bloomery process. Successes were obtained these last years by following the Os isotopic signature of the ore in the metal and, more recently, in the slag [13,14]. The Os isotope approach is nevertheless limited today by the fact that more work must be done to determine the discriminating power of the isotopic signature between different kinds of ores and production areas. Some studies [15] have shown that the Os approach, despite some overlapping between different ore sources, can be useful in complement with other approaches as the one based on trace elements (see below). Another recent approach deals with the Fe isotopic signature [16], whose discriminating power is however questioned [17]. Besides, another philosophy is to follow the chemical signature of the initial ore in the slag inclusions that remain embedded in the metal after the smelting process. This is today the most employed method and the one that brings more results [15,18-21]. Slag inclusions come from non-reduced compounds of the ore entrapped in the metal during the smelting stage [22]. The approach first needs to decipher this kind of inclusions from other ones that could come from later stages of the ironmaking process $[23,24]$. Regarding inclusions formed during smelting, one can consider that all the elements which do not pass into the metal keep their respective ratios from the ore to the slag inclusions in the artefact. This is true if there is no contamination from other compounds present in the raw materials used for smelting (mainly charcoal, furnace lining, or fluxes added during smelting). One solution to overcome this problem is to consider as the signature of a given production area, not the ore itself, but the slag remaining on the smelting sites. Another complementary strategy is to consider rare earth trace elements, which are less submitted to pollution effect and more discriminant than major elements [18]. For these reasons, it is important to stress that, only considering the major element composition of slag and slag inclusions is not sufficient to perform a significant provenance study. The important number of considered trace elements (commonly between 10 and 15, depending on the initial ore compositions) brings a high discriminating potential but requires to make use of multivariate statistical approaches to compare the chemical signatures. Different philosophies are employed: non supervised ones, hierarchical agglomerative clustering (HAC) and principal component analysis (PCA) [15,21] or supervised ones, linear discriminant analyses (LDA) [19,25]. Both approaches have their advantages and limits and the best way is to combine these two statistical inferences. This will be shown in the present study.

The present study focuses on the case of Bourges Cathedral, built in the first half of the 13th century. It was recently proven that an iron chain and great tie-rods were used in its original structure during the two main construction phases (1195-1214 and 1225-1255) [2,26,27]. However, despite the size of these armatures and their absolute necessity in the cathedral structure, no accounting records nor historical sources are available to document their supply and its potential evolution during the different campaigns of construction. The city of Bourges is yet surrounded by iron production districts which are active at least from the late iron age, up until the contemporary period, with the activity 
of several hydraulic forges and blast furnaces [28]. Significant archaeological remains from these ancient workshops and industries remain to be studied to unravel the modalities of iron trade and their evolution during the last centuries of the Middle Ages.

\section{Samples and Analytical Methodologies}

\subsection{Sampling of Iron Armatures}

Two sets of iron samples were considered in the structure of Bourges Cathedral (Figure 1):

- a $100 \mathrm{~m}$ long iron chain made of at least 106 elements, surrounding the eastern parts of the cathedral at the triforium level (Figure 2 left);

- 4.5 to $5 \mathrm{~m}$ long tie-rods consolidating the arches of the inner aisle at the same level (Figure 2 right).

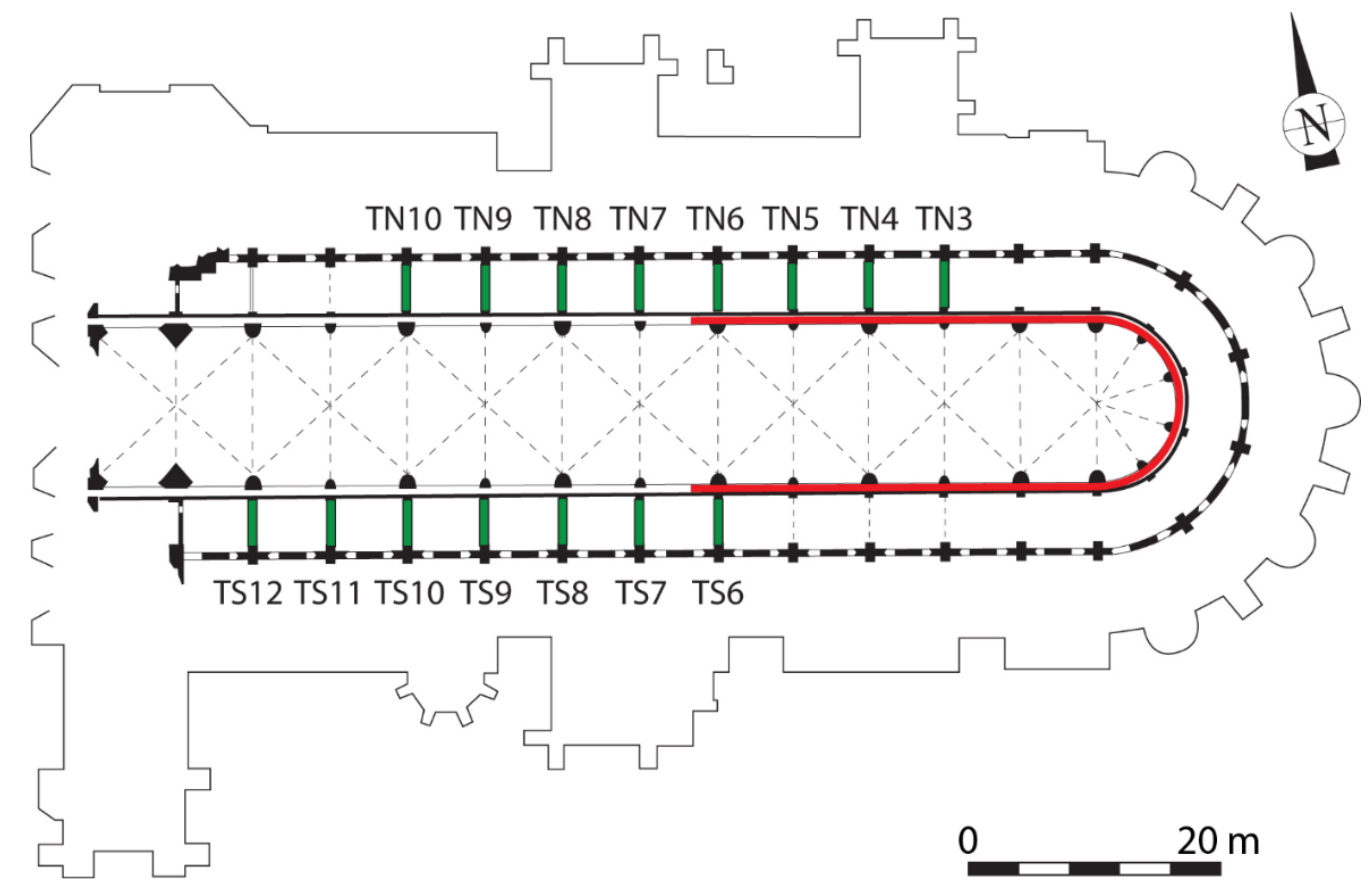

Figure 1. Map of Bourges Cathedral showing the studied iron reinforcements: attic tie-rods in green and triforium chain in red. Drawing from the authors after Férauge and Mignerey [26].

The archaeological and morphological analyses carried out on these iron armatures showed that they were installed during the original construction campaigns of the cathedral [26]: before 1214 for the chain and the eastern tie-rods and between 1225 and 1255 for the western tie-rods, beyond the 7th bay (dates according to Branner [29,30]). These conclusions were endorsed by the radiocarbon dating of a charcoal stuck in the mortar sealing parts of the chain and of some iron chain links themselves [2] as well as by a broad laser-scanning operation conducted on the building and showing the deformations that occurred during the first construction campaign which led to the installation of both the chain and the eastern tie-rods [31]. The chosen elements therefore belong to two different construction phases and two different sets: big iron bars weighing about $40 \mathrm{~kg}$ and smaller iron links weighing about 5 to $9 \mathrm{~kg}$. In order to evaluate the possible link between the type of iron product and its origins, the sampling strategy for provenance analyses was therefore carried out as follows. Regarding the iron chain, the largest number of links was considered. For mechanical purposes, sampling was performed on the links corners, where possible, on the entire length of the iron chain to ensure statistical representativeness. On a few links, two samples were taken on both sides to check their homogeneity. Overall, 59 samples were cut on 56 different links (Table 1). On the other hand, the 13 
tie-rods were all considered for the study and several samples were systematically taken from each tie-rod (usually 3 or 4 ) in order to determine the homogeneity of each bar (Table 2). When welding marks could be observed on the tie-rods (Figure 3), the samples were cut from either side of them. As the bars are still anchored within the building structure, only small notches of a few mm could be sampled. Larger samples could be taken on one of the bars which was already broken (TN7). Overall, 99 iron samples were analyzed on the bars and chains in order to study the iron provenance and to evaluate its possible evolution in time during the 13th century and the impact of the type and size of iron products on their supply.

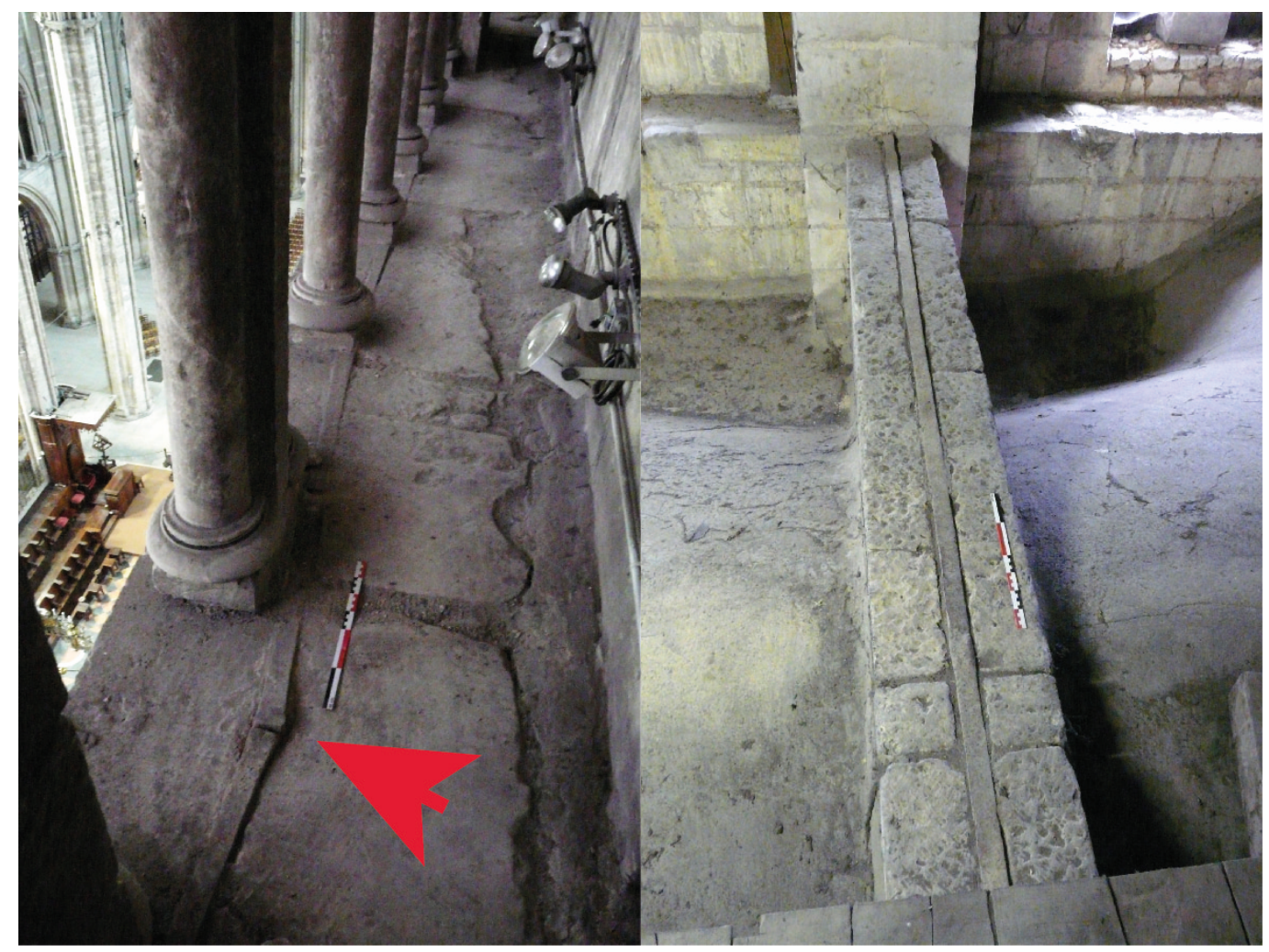

Figure 2. (left) Triforium chain (red arrow). View of the north side in the 2nd bay, (right) Attic tie rod TN4.

\subsection{Iron Production around Bourges and Slag Sampling}

Regarding iron production, the region of Bourges has been the seat of intense metallurgical activity since the Bituriges Cubi occupation, as witnessed by Julius Caesar himself during the siege of Avaricum (Bourges) [28]. Written and archaeological sources confirm the continuation of this activity in the medieval period particularly in the nearby forest of Allogny, about $15 \mathrm{~km}$ north of Bourges [32,33]. A 13th century cartulary reveals that the Cistercian abbey of Loroy, which cultivates close links with members of the de Sully family and the archbishopric of Bourges, obtained the usufruct of ironworks in Saint-Palais forest (part of Allogny forest) on the lands of the archbishopric (Arch. dép. Cher, G 1, fol. 664 r.). A dispute between the Abbey of Saint-Sulpice de Bourges and the Lord of Mehun-sur-Yèvre, Robert de Courtenay, over the extraction of ore and forestry forges also testify their presence [32]. More than a hundred iron production sites were discovered during pedestrian prospections led between the late 1980s and the years 2000 [32,33]. Renewed prospecting in the Allogny forest between 2009 and 2012 on 8 of these sites with dating objectives and a consecutive archaeological survey carried out on the site of Bléron [34] allowed the collection of 144 slag samples for analysis (Table 3 and Figure 4). 
Table 1. Samples of the iron chain.

\begin{tabular}{|c|c|c|c|}
\hline Bay & Number of Analyzed Links & Number of Analyzed Samples & Samples References \\
\hline Apse & 11 & 11 & $\begin{array}{c}\text { CHABS41, CHABS43, CHABS46, } \\
\text { CHABS47, CHABS51, CHABS53, } \\
\text { CHABS55, CHABS58, CHABS61, } \\
\text { CHABS62, CHABS63 }\end{array}$ \\
\hline North 1 & 4 & 4 & CH1N34, CH1N35, CH1N36, CH1N40 \\
\hline North 2 & 3 & 3 & $\mathrm{CH} 2 \mathrm{~N} 27, \mathrm{CH} 2 \mathrm{~N} 32, \mathrm{CH} 2 \mathrm{~N} 33$ \\
\hline North 3 & 5 & 6 & $\begin{array}{c}\text { CH3N20, CH3N21, CH3N22, CH3N23, } \\
\text { CH3N24E, CH3N24W }\end{array}$ \\
\hline North 4 & 5 & 6 & $\begin{array}{l}\text { CH4N13E, CH4N13W, CH4N14, } \\
\text { CH4N15, CH4N16, CH4N17 }\end{array}$ \\
\hline North 5 & 5 & 6 & $\begin{array}{c}\text { CH5N10E, CH5N10W, CH5N6, CH5N7, } \\
\text { CH5N8, CH5N9 }\end{array}$ \\
\hline North 6 & 3 & 3 & CH6N1, CH6N2, CH6N3 \\
\hline South 1 & 6 & 6 & $\begin{array}{l}\text { CH1S65, CH1S66, CH1S67, CH1S68, } \\
\text { CH1S69, CH1S70 }\end{array}$ \\
\hline South 2 & 5 & 5 & $\begin{array}{c}\mathrm{CH} 2 \mathrm{~S} 73, \mathrm{CH} 2 \mathrm{~S} 74, \mathrm{CH} 2 \mathrm{~S} 75, \mathrm{CH} 2 \mathrm{~S} 76, \\
\mathrm{CH} 2 \mathrm{~S} 77\end{array}$ \\
\hline South 3 & 2 & 2 & $\mathrm{CH} 3 \mathrm{~S} 83, \mathrm{CH} 3 \mathrm{~S} 85$ \\
\hline South 4 & 4 & 4 & CH4S88, CH4S90, CH4S91, CH4S92 \\
\hline South 5 & 1 & 1 & CH5S96, \\
\hline South 6 & 2 & 2 & CH6S101, CH6S102 \\
\hline Total & 56 & 59 & \\
\hline
\end{tabular}

Table 2. Samples of the iron tie-rods.

\begin{tabular}{ccc}
\hline Tie-Rod Reference & Location (Bay) & Number of Analyzed Samples \\
\hline TN3 & North 2-3 & 4 \\
\hline TN4 & North 3-4 & 4 \\
\hline TN5 & North 4-5 & 3 \\
\hline TN6 & North 5-6 & 4 \\
\hline TN7 & North 6-7 & 3 \\
\hline TN8 & North 7-8 & 2 \\
\hline TN9 & North 8-9 & 3 \\
\hline TS6 & South 5-6 & 3 \\
\hline TS7 & South 6-7 & 2 \\
\hline TS8 & South 7-8 & 5 \\
\hline TS9 & South 8-9 & 3 \\
\hline TS10 & South 9-10 & 1 \\
\hline TS11 & South 10-11 & 3 \\
\hline Total & & 40 \\
\hline
\end{tabular}

South of Bourges, a dozen sites linked to iron metallurgy have been discovered by archaeological surveys following the construction of the A 77 route in the Farges-Allichamps and Nozières region [35]. A few sites were dated from the Gallo-Roman period and others from the medieval times. The latter could be linked to the neighboring Cistercian abbey of Noirlac, whose archives attest to the importance of iron production in the 13th century [36]. At last, one site (La Beaume) produced iron according to the indirect process. New prospections were carried out between 2009 and 2012 in the vicinity of Noirlac Abbey on six of these sites and 78 slag samples were collected for analysis (Table 3 and Figure 4). 


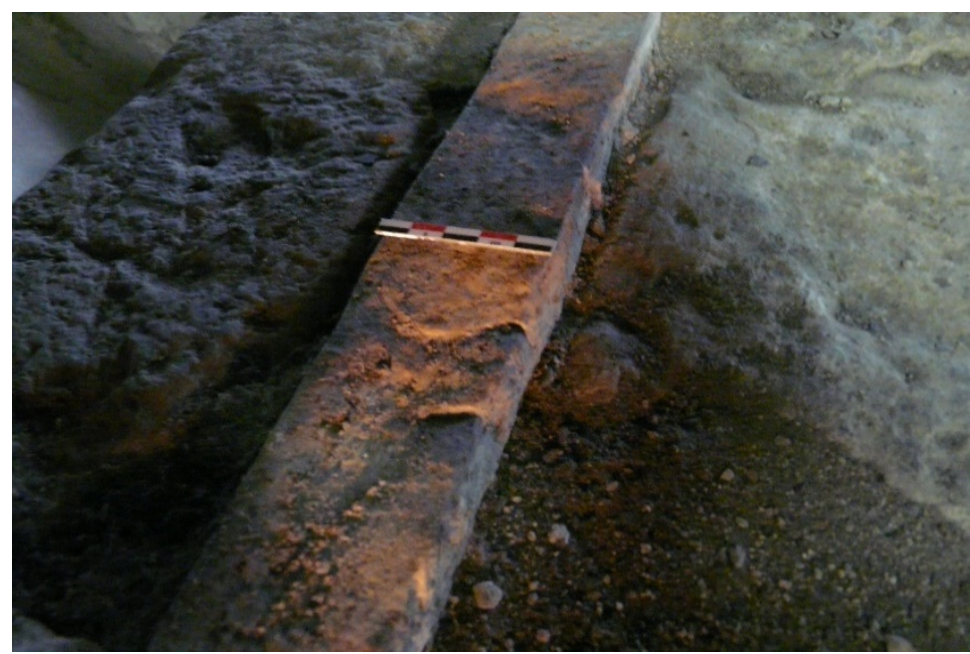

Figure 3. Welding line observed on TN3 tie-rod.

Table 3. Site and slag studied corpus.

\begin{tabular}{|c|c|c|c|c|c|c|c|}
\hline $\begin{array}{l}n^{\circ} \text { on } \\
\text { Map }\end{array}$ & Site & Ref. & City & Period & Dating Method & $\begin{array}{l}\text { Analyzed } \\
\text { Slag }\end{array}$ & $\begin{array}{c}\mathrm{Nb} \text { of } \\
\text { Analyses }\end{array}$ \\
\hline 1 & Le Parc & PA & Allogny & $\begin{array}{c}\text { 13th-15th c. } \\
\text { AD }\end{array}$ & 2 dates $\mathrm{C} 14$ & 18 & 18 \\
\hline 2 & $\begin{array}{l}\text { Les } \\
\text { Usages }\end{array}$ & US & $\begin{array}{c}\text { Saint-Eloy-de } \\
\text {-Gy }\end{array}$ & ? & - & 14 & 16 \\
\hline 3 & Bléron & BL & $\begin{array}{l}\text { Saint-Martin } \\
\text { d'Auxigny }\end{array}$ & 1st c. AD & 3 dates $\mathrm{C} 14$ & 38 & 43 \\
\hline 4 & $\begin{array}{l}\text { La Main } \\
\text { Ferme }\end{array}$ & MA & $\begin{array}{c}\text { Saint-Eloy-de } \\
\text {-Gy }\end{array}$ & 2nd-4th c. AD & 3 dates $\mathrm{C} 14$ & 16 & 23 \\
\hline 5 & $\begin{array}{l}\text { Les } \\
\text { Barbotzies }\end{array}$ & BA & $\begin{array}{l}\text { Saint-Martin } \\
\text { d'Auxigny }\end{array}$ & Medieval? & $\begin{array}{l}\text { C14 (Bordeloup, } \\
\text { personnal } \\
\text { communication) }\end{array}$ & 18 & 18 \\
\hline 6 & Bubelle & $\mathrm{BU}$ & Vouzeron & $\begin{array}{l}\text { Late or post } \\
\text { medieval? }\end{array}$ & $\begin{array}{l}\text { Some blast } \\
\text { furnace type slags }\end{array}$ & 18 & 26 \\
\hline 7 & $\begin{array}{l}\text { La Motte } \\
\text { du fief }\end{array}$ & MF & Menetou-Salon & $?$ & - & 11 & 17 \\
\hline 8 & Le Latier & LA & Menetou-Salon & $?$ & $\begin{array}{c}- \\
\text { Total Allogny }\end{array}$ & $\begin{array}{c}11 \\
144\end{array}$ & $\begin{array}{c}11 \\
172\end{array}$ \\
\hline 9 & $\begin{array}{l}\text { Le Petit } \\
\text { Plaix }\end{array}$ & PP & Nozières & $\begin{array}{l}\text { 12th-13th c. } \\
\text { AD }\end{array}$ & Ceramics & 28 & 37 \\
\hline 10 & $\begin{array}{c}\text { La } \\
\text { Beaume }\end{array}$ & $\mathrm{BE}$ & Nozières & Postmedieval & $\begin{array}{l}\text { Hydraulic forge } \\
\text { Blast furnace slags }\end{array}$ & 20 & 21 \\
\hline 11 & $\begin{array}{c}\text { Les } \\
\text { Nounins }\end{array}$ & $\mathrm{LN}$ & $\begin{array}{l}\text { Farges- } \\
\text { Allichamps }\end{array}$ & $\begin{array}{l}\text { Roman and } \\
\text { early medieval }\end{array}$ & $\begin{array}{c}\text { Roman and early } \\
\text { medieval }\end{array}$ & 14 & 39 \\
\hline 12 & $\begin{array}{c}\text { Les } \\
\text { Petits } \\
\text { Champs }\end{array}$ & PC & $\begin{array}{l}\text { Farges- } \\
\text { Allichamps }\end{array}$ & $\begin{array}{l}\text { 12th-13th c. } \\
\text { AD }\end{array}$ & Ceramics & 10 & 10 \\
\hline 13 & $\begin{array}{c}\text { Les } \\
\text { Rougeaux }\end{array}$ & LR & $\begin{array}{c}\text { Farges- } \\
\text { Allichamps }\end{array}$ & Medieval? & Ceramics & 3 & 8 \\
\hline 14 & Cheval & $\mathrm{CH}$ & $\begin{array}{l}\text { Farges- } \\
\text { Allichamps }\end{array}$ & $?$ & - & 3 & 3 \\
\hline 15 & Raveau & RAV & Raveau & Post medieval & $\begin{array}{l}\text { Total Nozières } \\
\text { Hydraulic forge } \\
\text { Blast furnace slags }\end{array}$ & $\begin{array}{l}78 \\
4\end{array}$ & $\begin{array}{c}118 \\
4\end{array}$ \\
\hline 16 & $\begin{array}{c}\text { Le } \\
\text { Fournay }\end{array}$ & FNAY & $\begin{array}{l}\text { Jouet-sur- } \\
\text { l'Aubois }\end{array}$ & Post medieval & $\begin{array}{l}\text { Hydraulic forge } \\
\text { Blast furnace slags }\end{array}$ & 4 & 4 \\
\hline 17 & Coulanges & COUL & Le Chautay & Post medieval & $\begin{array}{l}\text { Hydraulic forge } \\
\text { Blast furnace slags }\end{array}$ & 4 & 4 \\
\hline 18 & Préçy & PRECY & Précy & Post medieval & $\begin{array}{l}\text { Hydraulic forge } \\
\text { Blast furnace slags }\end{array}$ & 4 & 4 \\
\hline & & & & & Total Aubois & 16 & 16 \\
\hline
\end{tabular}




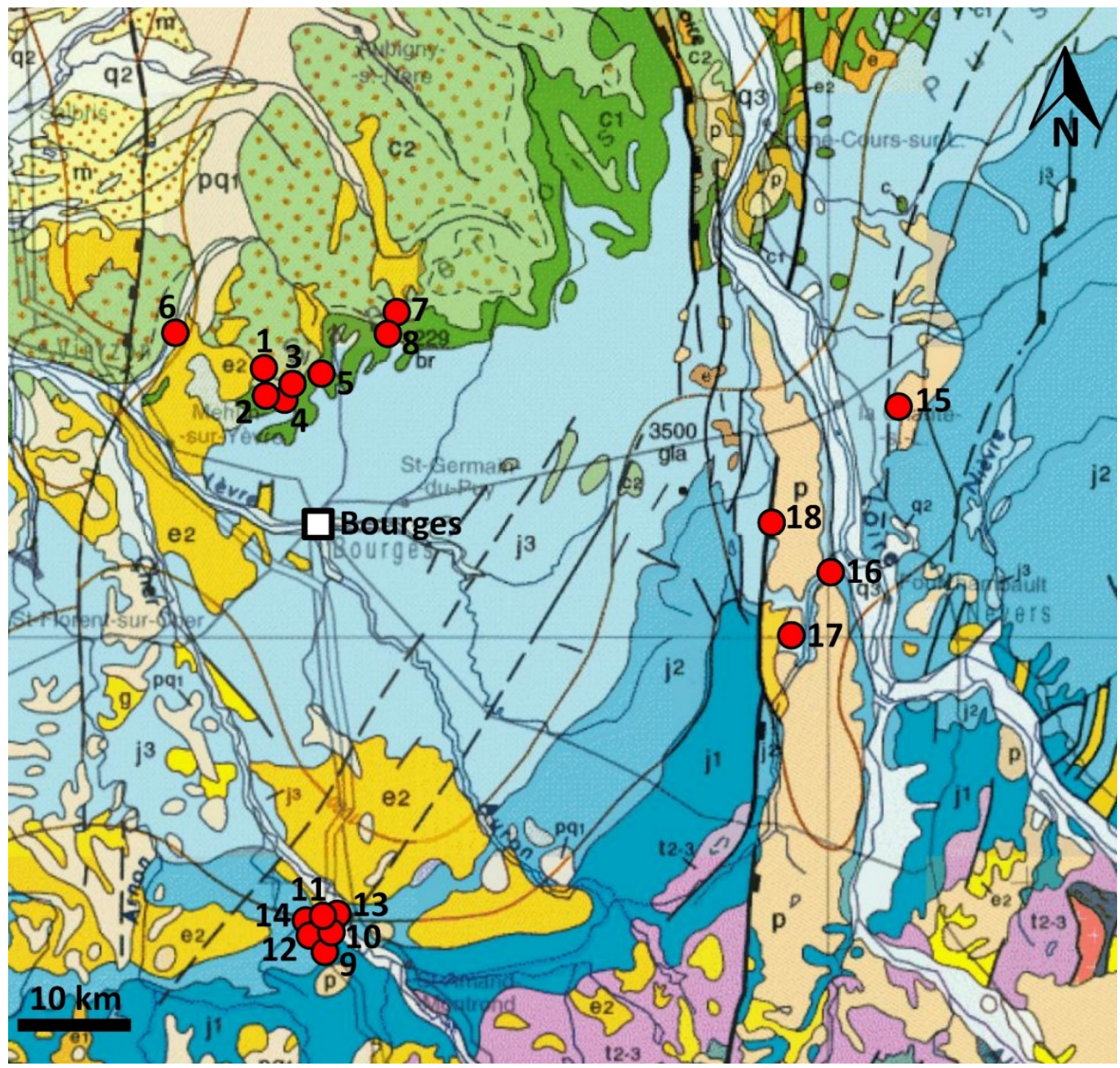

Figure 4. Location of the studied sites on a geological map.

Finally, intense metallurgical activity developed on the banks of the river Loire and its tributaries at the end of the Middle Ages with the very early introduction of indirect metallurgy from the beginning of the 15th century in the Val d'Aubois, next to La Charité-sur-Loire. Hydraulic forges indeed develop in Jouet-sur-l'Aubois (1401) and Précy (1402) in the vicinity of Fontmorigny abbey and in Raveau and Prye (1399) on the other side of the Loire river supposedly using local ores [37]. Although this production seems far too late to be of interest to the oldest parts of Bourges Cathedral, iron production could be more ancient in the region. A medieval charter dating from 1257 indeed reveals the existence of the "minières de Joet" (quarries of Joet) of which the use is acquired by the monks of Fontmorigny, and which may be located in the nearby Aubigny forest [38]. Prospections were however not carried out in this zone. Yet, the analytical corpus was much recently (September 2020) completed by prospections in the Val d'Aubois on four sites where blast furnaces early developed in the late Middle Ages. These last prospections allowed to increase the corpus with 16 new slags documenting this third region (Table 3 and Figure 4).

As a result of this work, around 240 slags were collected and over 300 analyses were performed. The slag composition could then be compared with that of the slag inclusions in the metal reinforcements of Bourges Cathedral. 


\subsection{Analytical Methods}

Prior to LA-ICP-MS trace element analysis, a rigorous protocol has to be followed to carry out a reliable provenance study $[18,19,39]$. First, a complete metallographic analysis has to be performed on each artefact to understand how it was forged and in particular to evaluate if it was forged from scrap iron or by welding different pieces of metal together. After mounting in epoxy resin and polishing using $\mathrm{SiC}$ abrasive paper (grade 80 to 1200 ) and diamond polishing (medium 9, 3 and $1 \mu \mathrm{m}$ ), a preliminary observation is performed on the sample using an optical microscope. This allows distinguishing the different kinds of inclusions and possible welding lines, suggesting different zones of interest on the artefact. Specific metallographic etching such as Nital or Oberhoffer etchings are also used at this stage to reveal the carbon and phosphorus content and better identify these potential features in the metallic structure. If welding lines are observed and delimitate specific areas in the sample (linked to the shape of the object or not), then each delimited zone has to be considered separately in the following steps.

Second, relevant slag inclusions (SI) for provenance studies have to be selected in each zone of interest. SI are indeed mainly produced during the reduction process but they can also originate from flux during forging. Local enrichment effects mainly due to small SI can be observed as well. Major composition analyses of SI are performed using energy dispersive spectrometry EDX with silicon drift detector-SDD) with a large window (about 90,000 c s1) coupled to a scanning electron microscope (SEM-FEG JEOL 7001-F) using a $15 \mathrm{kV}$ accelerating voltage, and a probe current of about $8 \mathrm{nA}$. SI are detected by image analysis of the back-scattered electrons signal. The Aztec Software (OxfordCompany) is used for particle detection and spectra processing. At least 50 SI per zone of interest on the sample should be analyzed $[23,24]$ and usually several hundred are considered.

Selecting SI which come from the smelting stage (i.e., characteristic of the reduction system: ore, fuel, lining, flux, etc.) can easily be done using their non-reduced compounds (NRC) ratios (i.e., $\mathrm{Al}_{2} \mathrm{O}_{3}, \mathrm{SiO}_{2}$, $\mathrm{MgO}, \mathrm{CaO}, \mathrm{K}_{2} \mathrm{O}$ ) which are constant throughout the sample [23]. SI whose compositions vary from these ratios are likely to come from the use of flux (antioxidants such as sand) during forging or to have undergone phase partitioning during the chaine opératoire. In both cases, these SI cannot be considered for provenance studies and should be discarded from any trace element analysis. Moreover, if different zones of interest within the same object present distinct NRC ratios, the object was likely forged out of iron pieces coming from different smelts and maybe from different origins. Such observations are common on iron objects coming for recycling of scrap iron. Such an object should be noted apart as "inhomogeneous" or "recycled" (noted * in this paper). Provenance study can still be carried out regardless of this heterogeneity, then each zone of interest with a different NRC ratio should be considered separately during trace element analysis. If the NRC ratios are the same regardless of the welding lines, then it can be assumed that the welding is rather linked to the forging sequence and the object can be studied as a whole for provenance analysis. This first analytical steps therefore allow to consider which SI have the adequate composition and size $(>80 \mu \mathrm{m})$ to undergo trace element analysis.

Trace element analysis on slag and SI is performed using LA-ICP-MS at the Center Ernest-Babelon of the IRAMAT (Orléans) using the methodology developed by Gratuze et al. [40,41]. It is carried out with an Element XR mass spectrometer from Thermo Fischer Scientific and a VG UV microprobe ablation device (quadrupled frequency Nd: YAG operated at $266 \mathrm{~nm}$ ). For each iron sample, 9 to 12 SI are selected and analyzed per zone of interest. The concentrations of 39 elements are routinely determined in SI, among which up to 14 (Ce, Eu, Gd, Hf, $\mathrm{La}, \mathrm{Nb}, \mathrm{Nd}, \mathrm{Pr}, \mathrm{Sm}, \mathrm{Tb}, \mathrm{Th}, \mathrm{U}, \mathrm{Y}, \mathrm{Yb}$ ) are routinely used to characterize the geochemical signature of the object. Silicon is measured on the 28Si isotope and is used as internal standard by comparison with SRM610 standard.

For slag analysis, the analytical protocol developed for glass is used, allowing the measurement of both major and trace elements at the same time [42]. The concentration of 58 elements is thus determined. Each slag is analyzed twice and the concentration is calculated from the mean of both laser shots. Major element concentrations ( $\mathrm{Na}, \mathrm{Mg}, \mathrm{Al}, \mathrm{P}, \mathrm{K}, \mathrm{Ca}$ ), and in particular Fe concentration, are calculated using Corning B and Corning D standards in addition to SRM610. In both cases, the laser 
shot size is set at the largest possible (100 $\mu \mathrm{m}$ for slag and 80-100 um for SI depending on their size) and the laser frequency is set on $7 \mathrm{~Hz}$.

\subsection{Data Processing}

All multivariate statistical approaches were performed by using the R software [43]. For LDA, the "lda" function of the MASS package was used. For the PCA analyses, the "PCA" function of the FactoMineR package was used. The hierarchical clustering was performed by using the "hclust" function on Euclidian distances. The ward method was selected as advised by precedent studies (Charlton the quest of provenance).

Because of the iron reduction, causing a global enrichment of the elements remaining in the slag, the raw amounts of the elements cannot be used directly. They have to be normalized. Different ways of normalization are possible $[12,44,45]$, but we chose to perform the log ratio one, the most used in literature $[1,19]$. Trace element contents are normalized by a log ratio approach given by the equation:

$$
X_{E}=\ln ([E])-\frac{1}{N} \sum_{k=1}^{N} \ln \left(\left[E_{k}\right]\right)
$$

Given $\left[E_{k}\right]$, only the elements well quantified for the whole reference set are considered: $Y, \mathrm{La}, \mathrm{Ce}$, $\mathrm{Sm}$ and Eu. The resulting variables are named "Xij".

\section{Results}

Let us first consider the production areas alone. Figure 5 shows the results of the PCA approach regarding the four main discrimination axes (raw data can be found in Supplementary Materials). It appears that, despite a slight differentiation on one dimension ( $\mathrm{PC} 1 / \mathrm{PC} 3$ and $\mathrm{PC} 2 / \mathrm{PC} 3$ projections), the chemical signature of the production areas cannot be sharply separated by this approach. Some slight overlapping between slags from the different spaces remain.

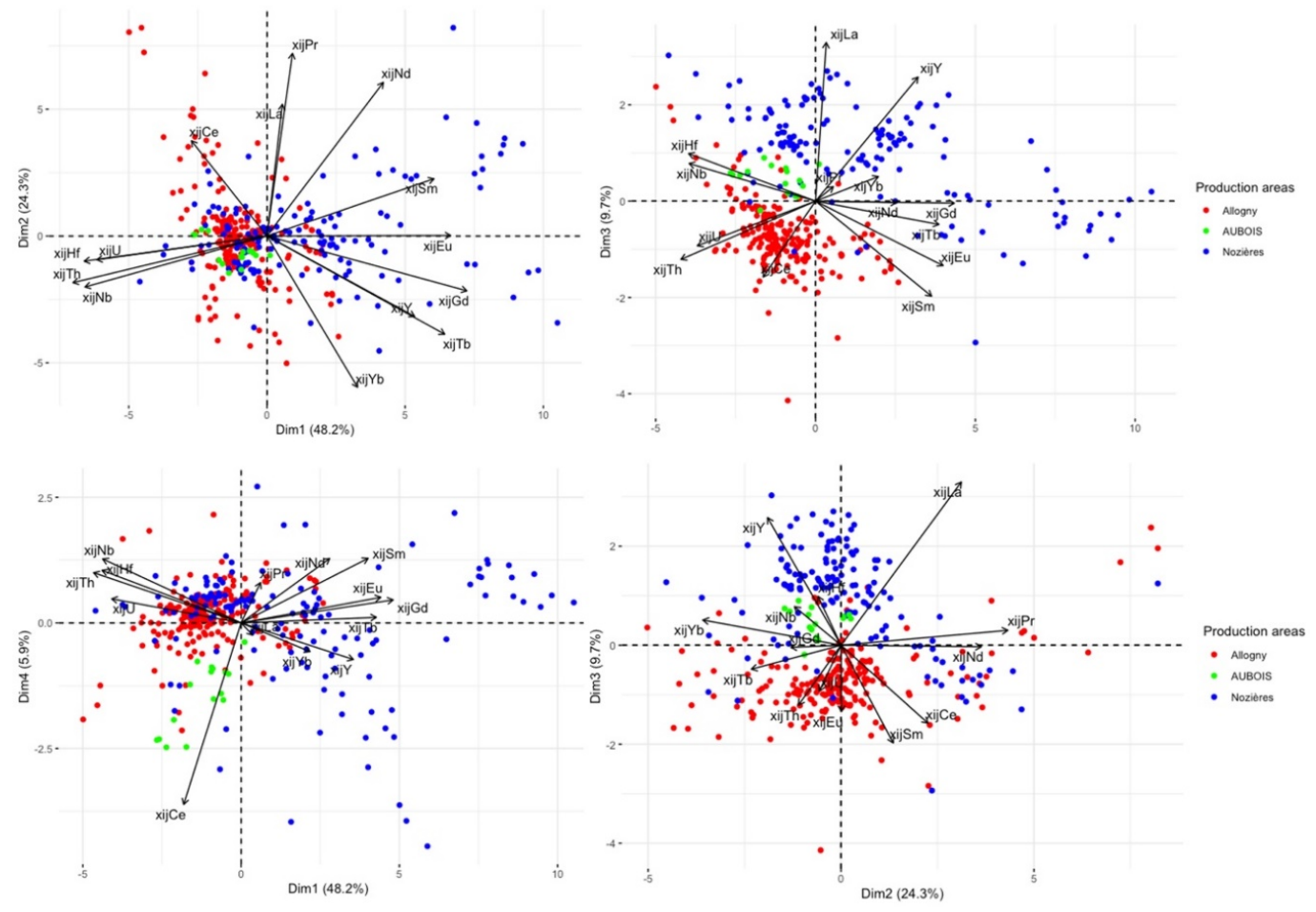

Figure 5. Principal Component Analysis (PCA) on the Xij of the production areas. 
A linear discriminant analysis on the $\mathrm{Xij}$ of the slag from the potential production area (Figure 6) shows a better separation of the chemical signature than with PCA, but a very slight overlapping between Allogny and Nozières remains (this observation is also true when only Allogny and Nozières are considered for the analysis-not shown). These observations have an important consequence in the following provenance attribution of the artefacts: potentially, it could be impossible to discriminate between these two production areas. Nevertheless, it can be expected that in most cases, the distinction should be possible. Moreover, the Aubois signature is sharply different if LDA is applied.

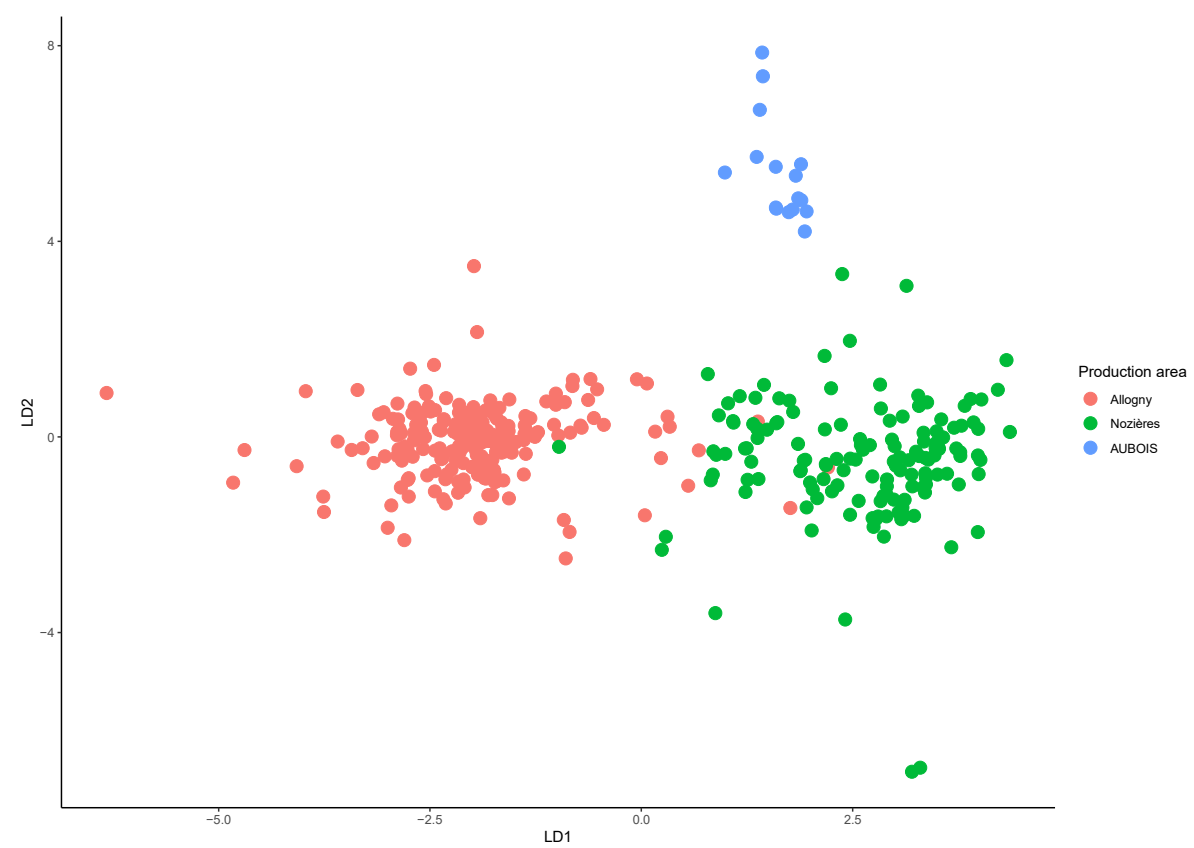

Figure 6. Linear discriminant analyses (LDA) on the Xij of the production areas.

Figure 7 shows the PCA results on the normalized data $\left(\mathrm{Xij}_{\mathrm{ij}}\right)$ from the complete set of samples (i.e., slag from Nozières, Allogny and Aubois areas and all the artefacts coming from the different locations in the cathedral). The projection on PC1 and PC2 highlights different clusters. A hierarchical agglomerative clustering (HAC) with 5 clusters, using Ward's method, allowed us to extract the samples corresponding to these different clusters. All the samples taken on the link of the chain located in the Apse (yellow dots on Figure 7) except a single one (CHABS61), are gathered in a same specific cluster (black dots on Figure 8). Some of the links from the south (blue) and north (purple) chain of the choir (CH1N34, CH1N35, CH1N36, CH1N40, CH1S66, CH2N33) also belong to this cluster named $\mathrm{C} 1$ in the following. The HAC also evidenced another cluster (red dots on Figure 8) that is constituted only by tie rods from both the northern and southern parts of the cathedral (TN8P1, TN8P2, TS11P2, TS11P3, TS7P1, TS7P2, TS9P1, TS9P2, TS10P1, TN9P2, TN9P3, TN9P4, TS6P1, TS6P2, TS6P3). This cluster will be named $\mathrm{C} 2$ in the following. Note that if one performs an HAC with 21 clusters, $\mathrm{C} 2$, can be separated in two sub-clusters: C2a containing TS6P1, TS6P2, TS6P3 and C2b containing the other ones (not shown). It is interesting to note that none of the considered production areas fits with these clusters which seem to have a very different trace element composition, with higher ratios of $\mathrm{Yb}, \mathrm{Tb}, \mathrm{Gd}, \mathrm{Eu}, \mathrm{Sm}, \mathrm{Y}$ compared to the other elements as illustrated in Figure 9. It is also worth noting that, for example, the $\mathrm{Nd} / \mathrm{Sm}$ ratios for these two clusters are sharply different than those of the other clusters (about 1.9 for $\mathrm{C} 1$ and C2a, 3 for $\mathrm{C} 2 \mathrm{a}$ and 4.5 for the other clusters). Such a low ratio is relatively unusual and was rarely reported in our former studies on trace slag and SI trace elements where $\mathrm{Nd} / \mathrm{Sm}$ is mostly around 4.5. Moreover, the rare production areas from our database with a similar $\mathrm{Nd} / \mathrm{Sm}$ are not chemically compatible with $\mathrm{C} 1$ and $\mathrm{C} 2$ when one considers all the other trace elements (not shown here). 


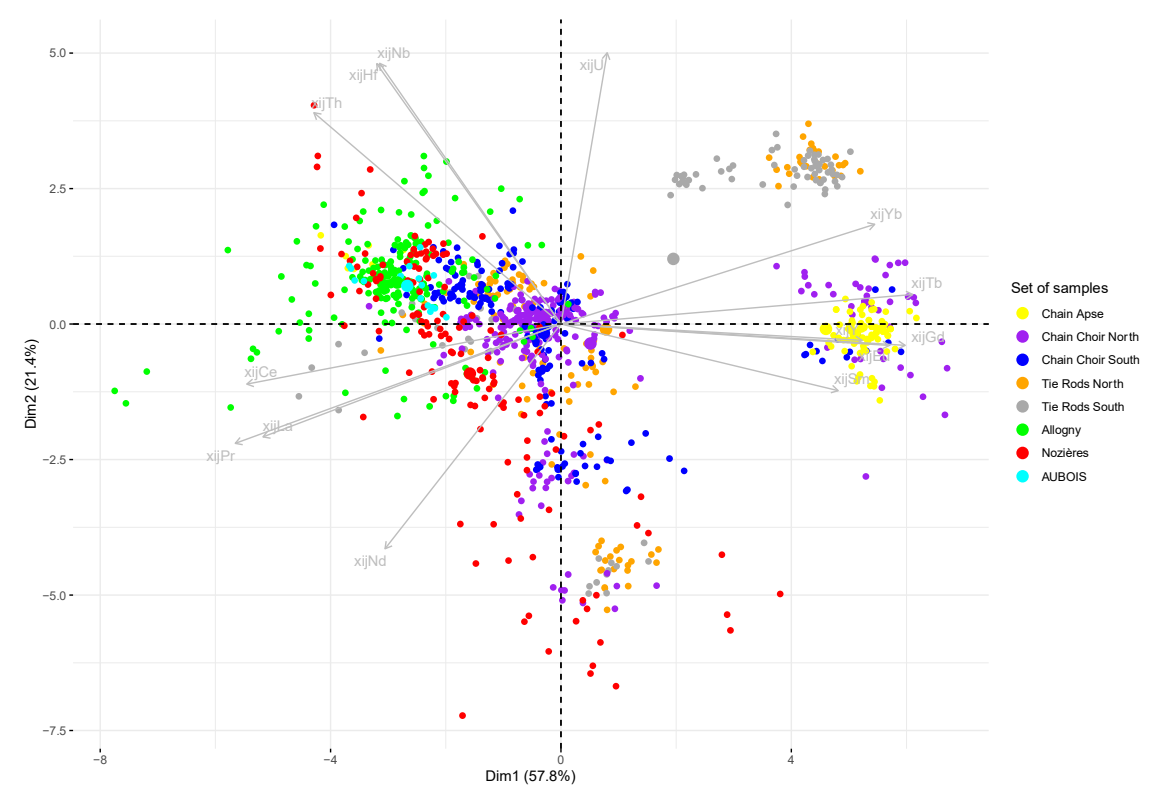

Figure 7. PCA on $\mathrm{Xij}$, three production areas and all objects from the different parts of the cathedral.

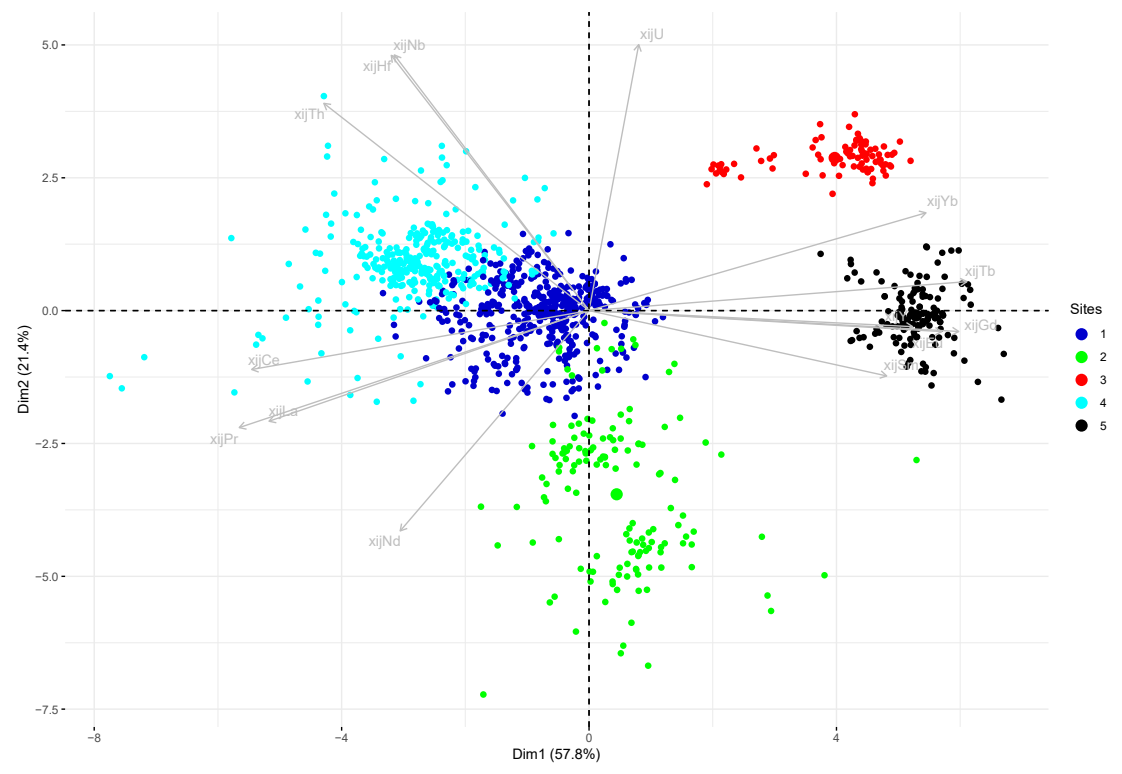

Figure 8. Results of a Hierarchical Agglomerative Clustering (HAC) (Ward's method) considering 5 clusters, plotted on the PCA/PC2 projections of the PCA analysis.

The production areas are distributed between the 3 other clusters evidenced by HAC, mixed with the rest of the artefacts. Further steps of the statistical inference must be implemented to determine provenance. The first one consists in making a linear discriminant analysis with two classes defined by a single artefact on the one hand and a given area of production of the other hand. Thus, 3 (areas) $\times 69$ (artefacts) $=207$ tests are performed. It is worth to note that a predictive approach by LDA cannot be attempted because unknown production areas exist but are not taken into account by the inference. What can be done is only a graphical analysis of the LDA results. Different cases can then be considered. The coordinates of the LDA scores of the tested production area and the ones of the object cannot be sharply separated graphically (see Figure 10 for examples) or, on the contrary, they are sharply separated (see Figure 11 for example). In the first case, because the principle of LDA is to maximize the interclass distances and to minimize the intraclass distances, one can consider that the signature of 
the artefact and the production area are very close and that the probability of the tested artefact to come from the considered production area is very high. Table 4 shows the list of samples that can be associated to one or another provenance. In the other case (when artefacts are separated), because of the same principle of LDA (to maximize interclass distances), the ruling out of the provenance hypothesis needs a supplementary step (see below). Lastly, the chemical signature of one sample (CHABS61) could not be separated from two production areas (Nozières and Allogny). Let us recall that these two production areas share a slight overlapping zone when compared by LDA (Figure 6), which could explain this result for CHABS61.
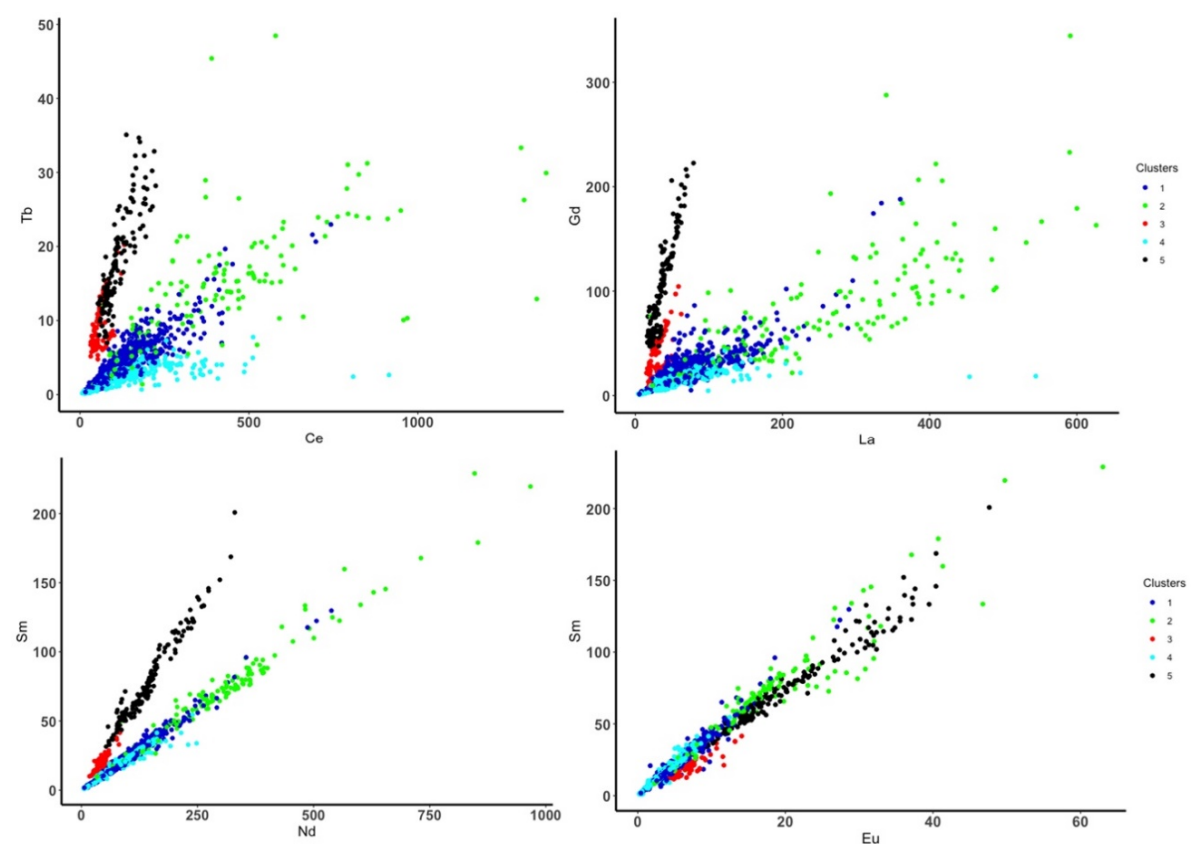

Figure 9. Examples of element ratios distinguishing clusters $\mathrm{C} 1$ and $\mathrm{C} 2$ from the rest of the samples. Numbers: clusters of the HAC.
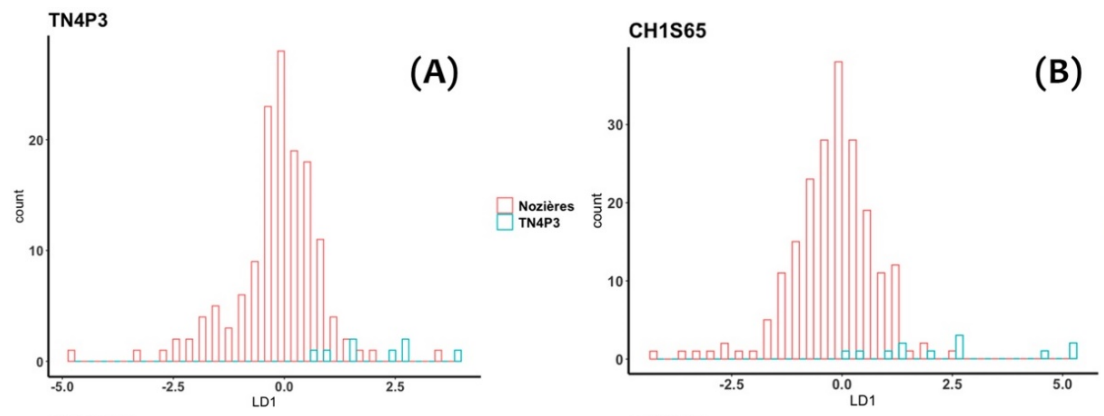

(B)
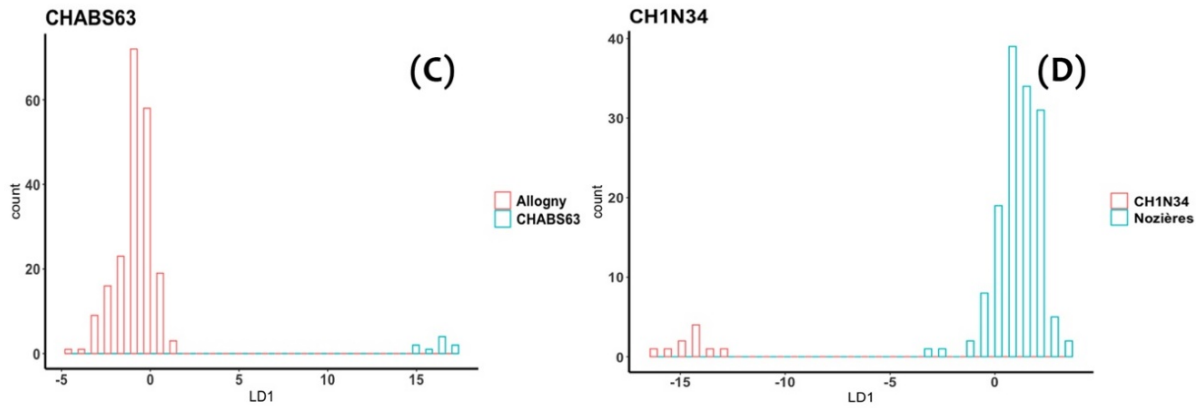

Figure 10. (A,B) LDA between an artefact and a production area, examples of compatibility, (B,C) LDA between an artefact and a production area, examples of exclusions. 


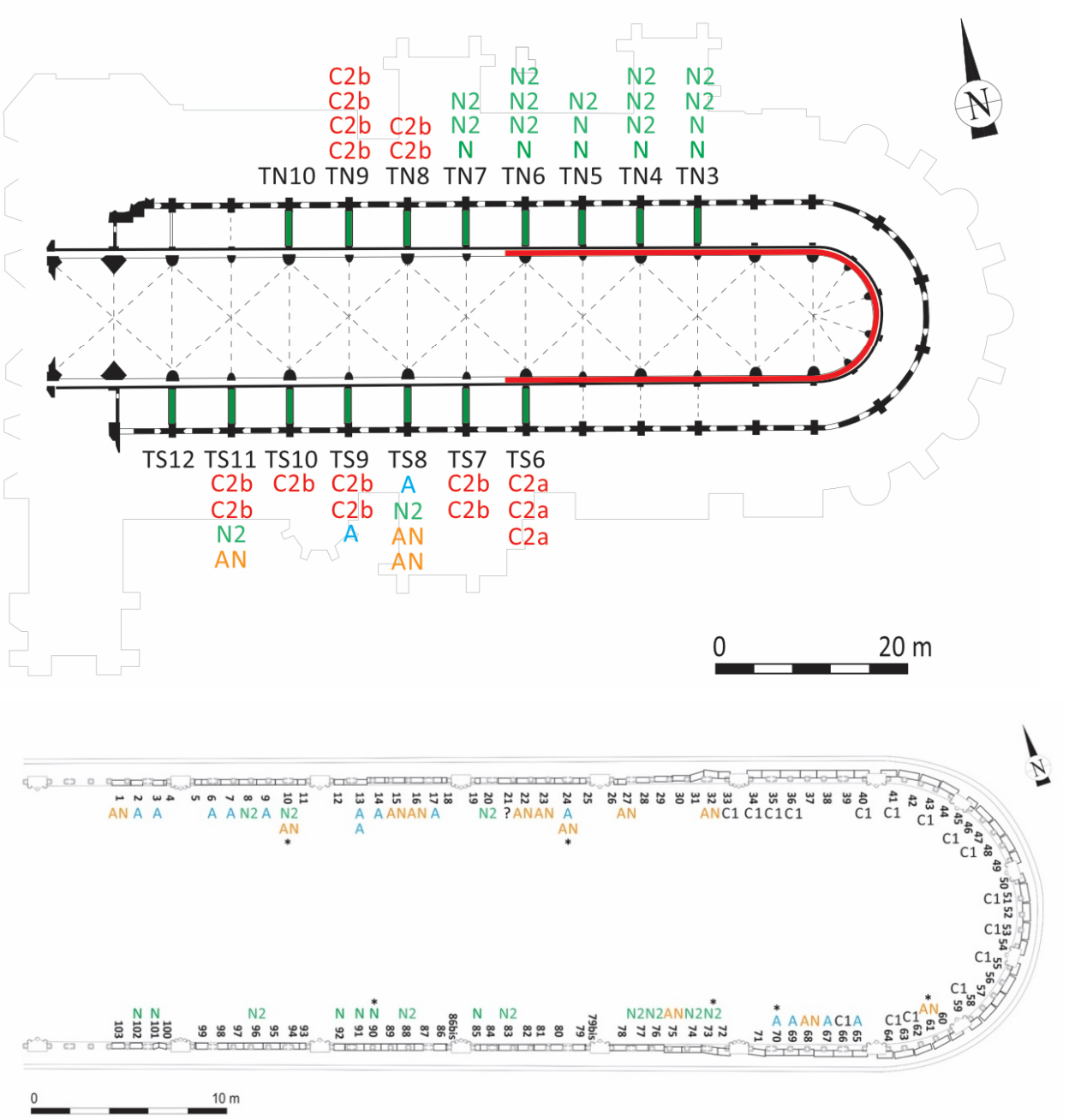

Figure 11. Provenance groups of the artefacts located in the cathedral, tie rods parts-each provenance corresponds to a given part of the bar, links of the triforium chain $\left({ }^{*}=\right.$ recycled, $?=$ unknown provenance).

Table 4. Results of the LDA analyses comparing one single artefact with a single production area (* indicates recycled samples characterized by metallographic and elemental analyses).

\begin{tabular}{|c|c|c|}
\hline Provenance Group & Samples from Tie Rods & Samples from the Chain Links \\
\hline Allogny & TS8P5, TS9P3 & $\begin{array}{c}\text { CH1S65, CH1S67, CH1S69, CH1S70*, } \\
\text { CH3N24W *, CH4N13E, CH4N13W, } \\
\text { CH4N14, CH4N17 *, CH5N6, CH5N7, } \\
\text { CH5N9, CH6N2, CH6N3 }\end{array}$ \\
\hline Nozières & $\begin{array}{l}\text { TN3P1, TN3P2, TN4P3, TN5P1, } \\
\text { TN5P2, TN6P3, TN7H+ b }\end{array}$ & $\begin{array}{c}\text { CH3S85, CH4S90 * CH4S91, CH4S92, } \\
\text { CH6S101, CH6S102 }\end{array}$ \\
\hline Allogny and Nozières & None & CHABS61 \\
\hline Aubois & None & None \\
\hline No attribution & $\begin{array}{c}\text { TN3P3, TN3P4, TN4P1, TN4P2, } \\
\text { TN4P4, TN5P3, TN6P1, TN6P2, } \\
\text { TN6P4, TN7F, TN7G, TN7H+, } \\
\text { TS11P1, TS8P1, TS8P2, TS8P3, } \\
\text { TS8P4 }\end{array}$ & $\begin{array}{c}\text { CH1S68, CH2N27, CH2N32, CH2S73 *, } \\
\text { CH2S74, CH2S75, CH2S76, CH2S77, } \\
\text { CH3N20, CH3N21, CH3N22, CH3N23, } \\
\text { CH3N24E * CH3S83, CH4N16, CH4S88, } \\
\text { CH5N10E * CH5N10W *, CH5N8, CH5S96, } \\
\text { CH6N1 }\end{array}$ \\
\hline
\end{tabular}

If one considers the last category of artefacts shown in Table 4, being the ones that were separated from all production areas by LDA, a PCA test was performed considering only a single production area and a single artefact. In addition, $39 \times 3$ tests were consequently performed. Again, different cases 
can be highlighted. The object cannot be separated from a single production area or from more than one production area, or, on the contrary, it can be separated by PCA. The results are shown in Table 5.

Table 5. Results of the PCA analyses comparing one single artefact with a single production area, (* indicates recycled samples characterized by metallographic and elemental analyses).

\begin{tabular}{|c|c|c|}
\hline Production Area & Samples from Tie Rods & Samples from the Chain Links \\
\hline Nozières & $\begin{array}{c}\text { TN3P3, TN3P4, } \\
\text { TN4P1, TN4P2, TN4P4, TN5P3, TN6P1, } \\
\text { TN6P2, TN6P4, TN7G, TN7H+, TS11P1, } \\
\text { TS8P3 }\end{array}$ & $\begin{array}{c}\mathrm{CH} 2 \mathrm{~S}_{3} *, \mathrm{CH} 2 \mathrm{~S} 74, \mathrm{CH} 2 \mathrm{~S} 76, \mathrm{CH} 2 \mathrm{~S} 77, \\
\mathrm{CH} 3 \mathrm{~N} 20, \mathrm{CH} 3 \mathrm{~S} 83, \mathrm{CH} 4 \mathrm{~S} 88, \mathrm{CH} 5 \mathrm{~N} 8, \\
\mathrm{CH} 5 \mathrm{~N} 10 \mathrm{~W} * \text {, CH5S96 }\end{array}$ \\
\hline Allogny & None & None \\
\hline Allogny and Nozières & $\begin{array}{c}\text { TS11P1, TS8P2, } \\
\text { TS8P4 }\end{array}$ & $\begin{array}{c}\text { CH1S68, CH2N27, CH2N32, CH2S75, } \\
\text { CH3N22, CH3N23, CH3N24E *, CH4N15, } \\
\text { CH4N16, CH5N10E * CH6N1 }\end{array}$ \\
\hline Aubois & None & None \\
\hline No Compatibility & & CH3N21 \\
\hline
\end{tabular}

To sum up, at the end of this complete statistical inference, artefacts (tie rods samples and links of the chain) can be distributed in different provenance categories:

- $\quad$ C1 and C2 (this latter divided in C2a and C2b) corresponding to unknown provenances, different of the tested production areas, but both having chemical similarities as far as REE signature is concerned.

- $\quad$ N: artefacts with a very high provenance probability from Nozières (not separable by a LDA approach).

- N2: Artefacts whose chemical signature is separated from the one of Nozières by a LDA approach but not by PCA. In the following discussion, they will be considered as coming from Nozières.

- $\quad$ A: artefacts with a very high provenance probability form Allogny (not separable by a LDA approach).

- $\quad$ AN: artefacts whose signature was compatible with both production areas (Allogny and Nozières) by LDA approach or by PCA approach.

- Un: artefacts not compatible with any production area by any approach. Other unknown origin than $\mathrm{C} 1$ and $\mathrm{C} 2$.

Figure 11 represents these different categories on the map of the cathedral, Tables 6 and 7 sum up the provenances for the different samples.

Table 6. Summary of provenances determined on the iron samples from Bourges Cathedral, (* indicates recycled samples characterized by metallographic and elemental analyses).

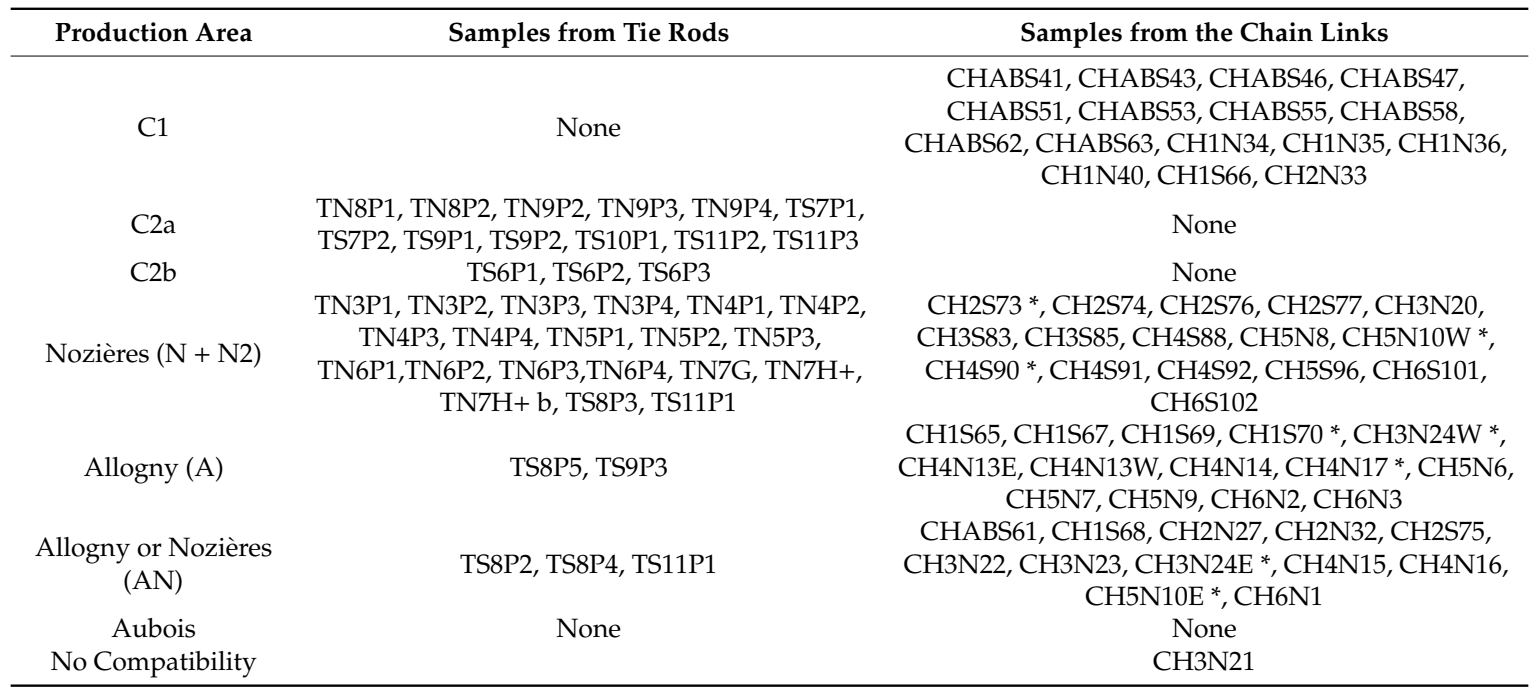


Table 7. Distribution of provenances regarding the type of iron armature.

\begin{tabular}{ccc}
\hline Production Area & Samples from Tie Rods: Bars (Samples) & Samples from the Chain Links \\
\hline C1 & 0 & 16 \\
C2 & $7(15)$ & 0 \\
Nozières N + N2 & $7(20)$ & 16 \\
Allogny & 2 & 13 \\
Allogny and Nozières & $2(3)$ & 12 \\
Aubois & 0 & 0 \\
No Compatibility & 0 & 1 \\
Recycled & Irrelevant & 6 \\
\hline
\end{tabular}

\section{Discussion}

\subsection{A Great Diversity of Supplies: Local and More Distant}

First, these results show the great diversity of the iron supplies for Bourges Cathedral building yard. At least four different production districts (Allogny forest, Nozières region and two or three unknown others, maybe close to one another, see below) were used by the master builders in order to reinforce the structure of the cathedral during the first half of the 13th century. The picture of iron supply for this construction phase is moreover quite complete as almost all the tie-rods were sampled and more than one chain link out of two. Such a clear picture highlighting the diversity of supplies in a single building yard over a time scale not longer than 50 years is unprecedented for a monument of the early 13th century. It is also very scarcely obtained for later monuments with written sources, which, however precise they are, never reveal such a great deal of provenance clues regarding half the iron bought and used by the building yards $[1,7,19,21,46]$. This highlights the strength of such archaeometric methodology to study iron circulation and trade in past societies.

Among these sources, local or regional supply indeed seems to prevail in the case of Bourges, as $70 \%$ (39/56) links of the chain come from the Allogny forest (about $15 \mathrm{~km}$ north) or the region of Nozières (about $45 \mathrm{~km}$ south). Evaluating the provenance of the tie-rods is more complex as some of them are forged from different pieces of metal (see below). However, half the studied tie-rods (6/13) are entirely made from local and regional productions. The prevalence of those areas situated about one day away (or less) from Bourges by terrestrial means of transportation such as carts (both regions being further away from waterways leading to Bourges) is quite notable in the absence of written sources. This picture recalls Odette Chapelot's assumptions claiming that for most building yards in the Chatillonnais (in Burgundy), iron usually mainly came from local or regional production areas [10]. However, among these local and regional productions, the Val d'Aubois region does not seem to have provided any iron supply during this period. Two hypotheses can be put forward. Whether iron production in the Val d'Aubois did not really spread before the introduction of hydraulic forges in the late 14th, early 15th centuries refuting the assumptions of Mathijs Schoevaert [38]: more archaeological prospections should be carried out in the region to confirm this hypothesis; or, on the other hand, another explanation could be that the iron produced in this area was rather traded along the Loire River than inlands.

Yet, about one third of the iron has a different signature from the three local and regional areas studied in this work, showing that more remote iron productions could also be traded and bought for the use of Bourges building yard. Two (or three) different chemical signatures $(\mathrm{C} 1, \mathrm{C} 2 \mathrm{a}$ and $\mathrm{b})$ were indeed identified. One striking feature is the homogeneity of the distribution of each of these productions in certain parts of the monument, indicating that they were sometimes massively exploited during the construction (see below) and consist in more than a punctual supply during all the building campaigns. Another striking feature is the chemical signature of both these areas. Even if they can clearly be distinguished from one another, they share certain features such as a distinct $\mathrm{Nd} / \mathrm{Sm}$ ratio from all the other productions. As the Eu/Sm ratio which is most of the time stable but can be used in certain cases to identify particular productions thanks to possible changes of Eu's oxidation degree [18], 
a different $\mathrm{Nd} / \mathrm{Sm}$ also reveals specific productions areas. However, the comparison with all the known production areas previously studied in France with a similar methodology $[15,18,19,21]$ showed that, even if a few ones have compatible $\mathrm{Nd} / \mathrm{Sm}$ ratios, their chemical signature is not compatible with the iron of Bourges. Even if locating these two or three zones remains impossible at present, this feature is a good indication that these chemical signatures come from close geological horizons (and therefore, probably geographical areas).

\subsection{Some Armatures Made of Iron from Different Origins}

Among chain links on which two samples were taken, some of them show a same provenance for both parts. This is the case for CH4N13E and W. On the contrary, CH3N24E and W, but also CH5N10E and $\mathrm{W}$, show two different chemical signatures, suggesting different provenances, indicating that the link was made with different parts of iron, likely recycled. CH5N10 is also endorsed by radiocarbon dating, showing a much older date than that of construction [2]. Studies on major elements (not presented here) corroborate these assertions and suggest CH2S73, CH4S90, CH4N17 and CH1S70 could be recycled too.

Unlike the chain links, it was proven that many tie-rods were forged by welding together iron pieces from different origins. This is at least the case for TS8, TS9 and TS11, mixing iron from up to three different origins: Allogny forest, Nozières region and the unknown C2 region, probably located further away. Even tie-rods TN3 to TN7, which seem entirely made with iron coming from the region of Nozières might as well have been forged from iron bars coming from different workshops, yet remaining inside the same production area, as slight differences in SI composition are observed between the different samples ( $\mathrm{N}$ and N2). This mix of iron from different sources within the same tie-rods is, in this case, not evidence of recycling: such great bars had to be forged from smaller masses of iron. Indeed, in ancient and medieval iron production processes, the iron bloom refining stage appears to be a bottleneck and primary iron masses of about 5-10 kg are much more easily obtained than bigger ones, regardless of the size of the bloom obtained in the furnace [47]. The present results therefore suggest that these massive tie-rods were not imported as a whole from a single bloomery controlling all the stages of iron production. They rather highlight the existence of at least one intermediate who gathered iron by-products (blooms or bars) to forge the tie-rods. They might therefore have been forged on demand either in a forge at the building yard, by an urban locksmith, whose iron supply can easily vary or even by a hydraulic smithy specialized in the fabrication of this kind of product. This last hypothesis might be most likely given the huge dimensions of these tie-rods and the hammer marks observed on some of them [26], as neither a regular urban locksmith nor the building yard were likely to have the suitable equipment to produce such armatures. However, in the lack of written sources, going further in the hypotheses is quite daring [21]. Putting into perspective the evolution of provenances with the different construction phases of the monument gives some more clues on iron trade and supply for Bourges building yard.

\subsection{Evolution of Provenances during Construction}

Lastly, let us draw a parallel between the identified iron production zones and the different construction phases of the monument. It was proven, thanks to an archaeological survey carried out in the triforium associated with analyses of the lead joints, that the chain was set in three distinct phases: apse and 1st bay, south (2nd-6th bay) and north (2nd-6th bay) most certainly in this order [26,48]. The eastern tie-rods are contemporary to the chain (before 1214), whereas the western ones (beyond the 6 th bay) where placed in a second and later construction campaign (1225-1255). The repartition of the iron signatures clearly matches the different construction campaigns and the three phases of the first campaign (Figure 11 and Table 8). The recycled samples are in minority and do not change the general trends observed. In the apse and the first bay, only $\mathrm{C} 1$ samples are present $(\mathrm{CH} 2 \mathrm{~N} 33$ can be associated with this group regarding the archaeological observations) with the exception of the first bay south where samples from Allogny are in majority. On the other hand, all the studied samples of 
the southern bays but one seems to come from the region of Nozières. Eventually, in the third phase, provenances are more mixed and include both local productions, yet with a prevalence of Allogny forest iron (9 samples). Seven samples could, however, not be distinguished between Allogny and Nozières. These observations reveal that very different production zones were called for in each of the three phases of the chain.

Table 8. Provenance per zones of the iron chain links.

\begin{tabular}{cccc}
\hline Production Area & Apse and 1st Bay & Northern Bays (2nd-6th) & Southern Bays (2nd-6th) \\
\hline C1 & 15 & 1 & 0 \\
C2 & 0 & 0 & 0 \\
Nozières (N + N2) & 0 & 3 & 13 \\
Allogny (A) & 4 & 9 & 0 \\
Allogny or Nozières (AN) & 2 & 9 & 1 \\
Aubois & 0 & 0 & 0 \\
No Compatibility & 0 & 1 & 0 \\
Recycled & 1 & 3 & 2 \\
\hline
\end{tabular}

The homogeneity of iron provenance in each phase, especially in the first two is quite striking. Even in the absence of written sources, these results allow to formulate some hypotheses. For the first two phases (east and south), apart from the few samples coming from Allogny, it seems rather unlikely that ordering theses armatures to a local smith in Bourges would result in such a great homogeneous production coming almost only from quite distant areas ( $\mathrm{C} 1$ area and Nozières, $45 \mathrm{~km}$ away from Bourges). It rather seems that the chapter directly treated with the aforementioned regions without intermediaries. The iron could therefore be a gift from some political power maybe following a request by the bishop or the chapter (Madeline 2009). It might also come from the income of the chapter's or bishop's land. The last possibility is that the chapter ordered the iron, whether forged or unforged, to an available smithy in the considered region. In either cases, the change of production in between the several phases seems to indicates that the supplying strategies of the building yard changed over time and that there is no durable association with a specific forge or region.

Taking into account the origins of the tie-rods consolidates and clarifies the whole picture. The north-eastern tie-rods (TN3-TN7) seem to originate solely from the forges of Nozières region, whereas the north-western ones (TN8-TN9) and almost all the southern ones (TS6-TS11 except TS8) contain iron from the further away C2 region. The "Branner break" delimitating the two main construction campaigns of Bourges Cathedral is approximately situated at the 6th bay, in which the iron chain stops [30]. The archaeological explorations clearly show that the 6th bay was under construction at that time, but at least part of the floor of the triforium was already built at this level. Tie-rods of rows 6 and 7 respectively lie before and beyond this bay and could be part of both construction campaigns (choir or nave). The match between TN7 and the eastern tie-rods could be in favor of a contemporary installation during the first campaign (choir, before 1214). Radiocarbon datings are not precise enough to endorse or refute this point [2]. On the other hand, the match between TS6 and the western tie-rods could rather indicate an installation during the second campaign (nave, 1225-1255). Let us also recall that TS6 has a specific and homogeneous signature (C2a). East of the Branner break, in the first construction campaign, the very good match between the provenance of the east northern tie-rods (TN3 to TN7) and the southern chain links (CH2S to CH6S-corresponding to bays 2 to 6) could suggest that both types of armatures were ordered and installed simultaneously. Archaeological observations associated with the laser scan made by Andrew Tallon [31] indeed revealed that the chain and the tie-rods could have been two solutions to the fact that the piers started to moved inwards and westwards the inside of the cathedral and needed to be more strongly attached to the rest of the masonry [26]. It is therefore very likely that they were ordered at the exact same time. These conclusions are in favor of a unique intermediate in the entire iron supply for this phase and suggest an order to a local smithy around Nozières. They could also simply reveal the economic 
or political predominance of this area of production, already equipped with hydraulic forges in the beginning of the 13th, whereas the much lesser importance of Allogny forest production in the tie-rods might also unveil the inexpediency of its workshops to produce locally such armatures.

In the next phase, the rather mixed origins for the northern chain can also be explained regarding archaeological observations. Indeed, it has been proven that contrary to the southern and apse parts of the chain, the northern part was not installed at once but that it was set separately in each bay [26]. Several orders might therefore have been placed for the supply, only for a few (5-6) links each. Moreover, one link per bay had to be forged at a precise dimension in order to close the chain in each bay. This is in good agreement with the greater heterogeneity observed and it is much more likely that these chain links were forged by an urban smith from Bourges, using a diversity of productions available in his stock, yet containing a good share of local productions (Allogny forest).

In the later construction campaign (Bay 7 to 12), beyond the Branner break, another change in iron supply is observed, as the $\mathrm{C} 2 \mathrm{~b}$ region seems mostly exploited at that time. Let us specify that at least 20 years separate the two campaigns and that a change in iron supply is here not surprising. However, it is interesting to point out that most of the iron might come from a region geologically (and geographically?) close to the one that was first used much earlier for the iron chain, mainly in the apse (C1). It clearly shows a close connection between Bourges and these more remote metallurgical districts, should it be for political or economic reasons. Contrary to the eastern tie-rods which were placed at the same time, following the observations of disorders in the masonry [26,31], the western ones could have been placed as the construction progressed westwards. However, the good consistency of the remote $\mathrm{C} 2 \mathrm{~b}$ region throughout all the tie-rods rather suggests that most tie-rods were purchased in a single phase. A mix of iron from different origins (Allogny, Nozières, C2b) is however observed in some tie-rods, showing that local and regional productions are still present and therefore rather suggesting that at least some of the tie-rods could have been forged or reforged more locally.

Having different supply sources for a single structure and even in a single bar is not scarce and can be due to several factors, as historical sources testify in other building yards. For example, when the fabric of Troyes Cathedral decides to consolidate the upper vaults in October 1410 and buys $75 \mathrm{~kg}$ great iron bars: six of them come from the distant great forge of Doulevant-le-Chateau located $70 \mathrm{~km}$ away from Troyes and yet others were given by sir Jean de Chaonnes, probably a canon of the Troyes Cathedral (AD Aube G 1559, fol. 171r) and therefore certainly do not come from the same source. Moreover, two years later, other bars of similar dimensions $(\approx 65 \mathrm{~kg})$ are bought for the same purpose to another great forge located in another region (Maraye-en-Othe, $15 \mathrm{~km}$ west of Troyes) (AD Aube, $\mathrm{G} 1561$, fol $\left.19 \mathrm{r}^{\circ}-19 \mathrm{v}\right)$. At least two or three different iron sources are therefore used here for the same structure. Furthermore, each time, the local locksmiths control the quality of these great bars and conclude that they are faulty and should be repaired, sometimes adding some of their "own" iron. Bourges Cathedral tie-rods are slightly smaller $(\approx 40 \mathrm{~kg})$ but remain in the same order of magnitude. Forging such great bars was always a challenge for metallurgists, even in the 15th century, maybe not always profitable for them [47]. Did the masters of the building yard collect the iron themselves, gathering different productions of unforged iron bars, like in Metz where the burgesses seem to control the iron production and importation in town, notably during the edification of the Mutte tower by the city [21], and then had the bars forged by a specialized smithy or a local workshop with a hydraulic equipment? Were the tie-rods forged in the C2 region and then reforged or adapted by local smiths with more local sources of iron such as in Troyes? Both hypotheses are valid and endorse the intensity of iron trade to supply this building yard at the beginning of the 13th century.

\section{Conclusions}

To conclude, this provenance study of the iron armatures of Bourges Cathedral demonstrates the powerfulness of the trace element approach when it is linked to a solid archaeological investigation, including production area definition, but also the study of the artefact to be sourced (especially on ancient monuments on which a time phasing can be proposed). Up to now, we believe that trace element 
approach is the most advanced and consolidated archaeomaterial approach (compared to isotopic approaches) to trace iron provenance, circulation and trade in a specific site or region. The study also illustrates the necessity to cross different statistical inferences (here HAC, PCA and LDA) to decipher provenance hypothesis on complex and heterogenous (not gaussians) sets of data.

In an historical point of view, this work allowed for the first time to study accurately iron circulation and trade around a single building yard over a time of 30 to 40 years with a precision never obtained before with historical sources. It shows that mainly four different metallurgical districts, local and more distant, supplied the building yard, mostly depending on the construction phases and also on the types of iron armatures needed. It allowed us to characterize the importance of the metallurgical activity and the potential equipment of each of the studied production area at that time, thus revealing that the closest production areas are not necessarily the major one used to supply such a construction site. Comparisons with historical sources on other buildings eventually allowed us to better understand the diversity of the provenances, even during a single construction campaign.

Supplementary Materials: The following are available online at http://www.mdpi.com/2075-163X/10/12/1131/s1, Table S1.

Author Contributions: M.L. and P.D. designed research; M.L. carried out the archaeological surveys; M.L. and P.D. did the sampling. M.L. and G.S. analysed samples; P.D. made the statistical analyses; M.L., P.D. and G.S. wrote the paper. All authors have read and agreed to the published version of the manuscript.

Funding: The research program FECOMEDA from the Région Centre funded part of the research and analyses and the Ministry of Culture (DRAC-Région Centre) funded part of the archaeological investigations. The most recent sampling and analyses were carried out through the "Métallurgie ancienne et aménagement hydraulique: analyse des interactions environementales historiques" project funded by the Labex DinamiTe.

Acknowledgments: The authors are grateful to P. Ponsot, Architecte en des Monuments Historiques and curator J.-P. Blin for letting them access to the Cathedral of Bourges and for the authorization of sampling. The authors would particularly like to thank Jean-Marie Bordeloup, Christophe Dunikowski and Emmanuèle Gautier-Costard for their field experience and their support during the archaeological prospections.

Conflicts of Interest: The authors declare no conflict of interest

\section{References}

1. L'Héritier, M.; Dillmann, P.; Benoit, P. Iron in the building of gothic churches: Its role, origins and production using evidence from Rouen and Troyes. Hist. Met. 2010, 44, 21-35.

2. Leroy, S.; L'Héritier, M.; Delqué-Kolic, E.; Dumoulin, J.-P.; Moreau, C.; Dillmann, P. Consolidation or initial design? Radiocarbon dating of ancient iron alloys sheds light on the reinforcements of French Gothic Cathedrals. J. Archaeol. Sci. 2015, 53, 190-201. [CrossRef]

3. Timbert, A. L'Homme et la Matière: L'Emploi du Plomb et du Fer dans l'Architecture Gothique; Actes du Colloque: Noyon, France, 2009.

4. L'Héritier, M.; Dillmann, P.; Timbert, A.; Bernardi, P. The role of iron armatures in gothic constructions: Reinforcement, consolidation or commissioner's choice. In Nuts and Bolt of Construction History. Culture, Technology and Society; Carvais, R., Guillerme, A., Nègre, V., Sakarovitch, J., Eds.; Picard: Paris, France, 2012; Volume 2, pp. 557-564.

5. Haas, W. Die rolle des eisens in der vorindustriellen arkitektur dargestellt an ostbayerischen beispielen. In Die Oberpfalz ein Europäisches Eisenzentrum 1600 Jahre Grosse Hammereinigung; Ostbayern Bergbau und Industrie Museum: Amberg, Germany, 1987; pp. 495-504.

6. Lefebvre, E. Les tirants de fer de la cathédrale Notre-Dame d'Amiens. In L'Homme et la Matière: L'Emploi du Plomb et du Fer dans l'Architecture Gothique; Timbert, A., Ed.; Picard: Paris, France, 2009; pp. 141-147.

7. Bernardi, P.; Dillmann, P. Stone skeleton or iron skeleton: The provision and use of metal in the construction of the Papal Palace at Avignon in the 14th century. In De Re Metallica. The Uses of Metal in the Middle Ages; Bork, R., Ed.; Ashgate: Aldershot, UK, 2005; Volume 4, pp. 297-315.

8. L'Héritier, M.; Dillmann, P. L'approvisionnement en fer des chantiers de construction médiévaux: Coût, quantités et qualité. L'exemple des églises de la période gothique. In Edifice et Artifice, Histoires Constructives; Carvais, R., Guillerme, A., Nègre, V., Sakarovitch, J., Eds.; Picard: Paris, France, 2010; pp. 457-466. 
9. Dillmann, P.; Perez, L.; Verna, C. (Eds.) Les aciers avant Bessemer. In L'acier en Europe Avant Bessemer; CNRS-Université de Toulouse-Le Mirail: Paris, France, 2011; pp. 7-69.

10. Chapelot, O.; Benoit, P. Pierre et Métal dans le Bâtiment au Moyen Age; EHESS: Paris, France, 1985.

11. Dillmann, P. De Soissons à Beauvais: Le fer des cathédrales de Picardie, une approche archéométrique. In L'Homme et la Matière: L'emploi du Plomb et du fer dans L'architecture Gothique; Timbert, A., Ed.; Picard: Paris, France, 2009; pp. 93-112.

12. Charlton, M.F. The last frontier in "sourcing": The hopes, constraints and future for iron provenance research. J. Archaeol. Sci. 2015, 56, 210-220. [CrossRef]

13. Brauns, M.; Yahalom-Mack, N.; Stepanov, I.; Sauder, L.; Keen, J.; Eliyahu-Behar, A. Osmium isotope analysis as an innovative tool for provenancing ancient iron: A systematic approach. PLOS ONE 2020, 15, e0229623. [CrossRef] [PubMed]

14. Schwab, R.; Heger, D.; Höppner, B.; Pernicka, E. The provenance of iron artefacts from Manching: A multi-technique approach. Archaeometry 2006, 48, 433-452. [CrossRef]

15. Dillmann, P.; Schwab, R.; Bauvais, S.; Brauns, M.; Disser, A.; Leroy, S.; Gassmann, G.; Fluzin, P. Circulation of iron products in the North-Alpine area during the end of the first Iron Age (6th-5th c. BC): A combination of chemical and isotopic approaches. J. Archaeol. Sci. 2017, 87, 108-124. [CrossRef]

16. Milot, J.; Poitrasson, F.; Baron, S.; Coustures, M.-P. Iron isotopes as a potential tool for ancient iron metals tracing. J. Archaeol. Sci. 2016, 76, 9-20. [CrossRef]

17. Rose, T.; Télouk, P.; Klein, S.; Marschall, H.R. Questioning Fe isotopes as a provenance tool: Insights from bog iron ores and alternative applications in archeometry. J. Archaeol. Sci. 2019. [CrossRef]

18. Desaulty, A.-M.; Dillmann, P.; L’Héritier, M.; Mariet, C.; Gratuze, B.; Joron, J.-L.; Fluzin, P. Does it come from the Pays de Bray? Examination of an origin hypothesis for the ferrous reinforcements used in French medieval churches using major and trace element analyses. J. Archaeol. Sci. 2009, 36. [CrossRef]

19. Leroy, S.; Cohen, S.X.; Verna, C.; Gratuze, B.; Téreygeol, F.; Fluzin, P.; Bertrand, L.; Dillmann, P. The medieval iron market in Ariège (France). Multidisciplinary analytical approach and multivariate analyses. J. Archaeol. Sci. 2012, 39, 1080-1093. [CrossRef]

20. Coustures, M.P.; Béziat, D.; Tollon, F.; Domergue, C.; Long, L.; Rebiscoul, A. The use of trace element analysis of entrapped slag inclusions to establish ore-Bar iron links: Examples from two Gallo-Roman iron-making sites in France (Les Martys, Montagne noire, and les Ferrys, Loiret). Archaeometry 2003, 45, 599-613. [CrossRef]

21. Disser, A.; Dillmann, P.; Leroy, M.; L'Héritier, M.; Bauvais, S.; Fluzin, P.H. Iron Supply for the Building of Metz Cathedral: New Methodological Development for Provenance Studies and Historical Considerations. Archaeometry 2017, 59, 493-510. [CrossRef]

22. Hørst-Madsen, L.; Buchwald, V.F. The characterisation and provenancing of ore, slag and iron from the Iron Age settlement in Snorup. J. Hist. Metall. Soc. 1999, 33, 57-67.

23. Dillmann, P.; L'Héritier, M. Slag inclusion analyses for studying ferrous alloys employed in French medieval buildings: Supply of materials and diffusion of smelting processes. J. Archaeol. Sci. 2007, 34, 1810-1823. [CrossRef]

24. Disser, A.; Dillmann, P.; Bourgain, C.; L'Héritier, M.; Vega, E.; Bauvais, S.; Leroy, M. Iron reinforcements in Beauvais and Metz Cathedrals: From bloomery or finery? The use of logistic regression for differentiating smelting processes. J. Archaeol. Sci. 2014, 42, 315-333. [CrossRef]

25. Hendrickson, M.; Leroy, S. Sparks and needles: Seeking catalysts of state expansions, a case study of technological interaction at Angkor, Cambodia (9th to 13th centuries CE). J. Anthropol. Archaeol. 2020, 57, 101141. [CrossRef]

26. L'Héritier, M. Les armatures de fer de la cathédrale de Bourges: Nouvelles données, nouvelles lectures. Bull. Monum. 2016, 174, 447-465. [CrossRef]

27. Férauge, M.; Mignerey, P. L'utilisation du fer dans l'architecture gothique: L'exemple de la cathédrale de Bourges. Bull. Monum. 1996, T154, 129-146. [CrossRef]

28. Dieudonné-Glad, N. La métallurgie du fer autour d'Avaricum (Bourges) dans l'Antiquité. Rev. Archéol. Cent. Fr. 1992, 31, 58-74.

29. Branner, R. The Cathedral of Bourges and its Place in Gothic Architecture; MIT Press: Cambridge, UK, 1989.

30. Branner, R. Le Maitre de la cathédrale de Beauvais. Art Fr. 1962, 2, 77-92. 
31. Tallon, A. La perpendicularité de la cathédrale de Bourges, enjeu de la perfection architecturale. Bull. Monum. 2016, 174, 425-446. [CrossRef]

32. Bordeloup, J.-L. Nouvelles observations sur la métallurgie ancienne du fer à Allogny (Cher). Bull. Groupe Rech. Archéol. Hist. Sologne 1995, 1, 143-158.

33. Landes, C.; Bordeloup, J.-L. Recherches récentes sur la forêt d'Allogny (Cher). Bull. Groupe Rech. Archéol. Hist. Sologne 1985, 7, 41-52.

34. L'Héritier, M. La Production du Fer au Moyen Age en Forêt d'Allogny. Prospection Thématique et Sondage sur le Site de Bléron; SRA Centre: Orléans, France, 2011.

35. Dunikowski, C. Etude d'un complexe métallurgique à Farges Allichamps (Centre). Rev. Archéol. Cent. Fr. 1987, 26, 85-86.

36. Ribault, J.-Y. L'abbaye cistercienne de Noirlac et la métallurgie du fer au XIIIe siècle. Lett. Noirlac 1991, 16, 14-17.

37. Belhoste, J.-F.; Léon, P. Naissance d'une sidérurgie moderne aux confins du Berry (fin du XIVe-XVe siècles). In Mélanges Jean-Yves Ribault; Cahiers D'Archéologie et d'Histoire du Berry: Bourges, France, 1996; pp. 45-51.

38. Schoevaert, M. La Métallurgie à Jouet sur l'Aubois: Le Moyen Âge. La Voix Patrim. L'industrie 2012, 28 , 3-12.

39. L'Héritier, M.; Leroy, S.; Dillmann, P. Bernard Gratuze Characterization of Slag Inclusions in Iron Objects. In Recent Advances in Laser Ablation ICP-MS for Archaeology; Dussubieux, L., Golitko, M., Gratuze, B., Eds.; Springer: Berlin, Germany, 2016; pp. 213-228.

40. Gratuze, B. Obsidian characterisation by laser ablation ICP-MS and its application to prehistoric trade in the Mediterranean and the Near East: Sources and distribution of obsidian within the Aegean and Anatolia. J. Archaeol. Sci. 1999, 26, 869-881. [CrossRef]

41. Gratuze, B.; Blet-Lemarquand, M.; Barrandon, J.-N. Mass spectrometry with laser sampling: A new tool to characterize archaeological materials. J. Radionalytical Nucl. Chem. 2001, 247, 645-656. [CrossRef]

42. Gratuze, B. Glass Characterization Using Laser Ablation-Inductively Coupled Plasma-Mass Spectrometry Methods. In Recent Advances in Laser Ablation ICP-MS for Archaeology; Dussubieux, L., Golitko, M., Gratuze, B., Eds.; Springer: Berlin, Germany, 2016; pp. 179-196.

43. R Core Team R: A Language and Environment for Statistical Computing. Available online: https://www.Rproject.org/ (accessed on 9 November 2020).

44. Aitchison, J. Some comments on compositional data analysis in archaeometry, in particular the fallacies in Tangri and Wright's dismissal of logratio analysis. Archaeometry 2002, 44, 295-304. [CrossRef]

45. Baxter, M.J.; Freestone, I.C. Log-ratio Compositional Data Analysis in Archaeometry. Archaeometry 2006, 48, 511-531. [CrossRef]

46. L'Héritier, M. Le fer et le plomb dans la construction monumentale au Moyen Âge, de l'étude des sources écrites à l'analyse de la matière. Bilan de 20 ans de recherches et perspectives. ÆEdificare 2019, 6, 79-121.

47. Pages, G.; L'Héritier, M. La circulation du fer brut dans la Gaule antique et la France médiévale: Nouvelles perspectives. In Le Marché des Matières Premières dans l'Antiquité et au Moyen Age; Boisseuil, D., Rico, C., Gelichi, S., Eds.; Ecole Française de Rome: Rome, Italy, 2020.

48. L'Héritier, M.; Arles, A.; Disser, A.; Gratuze, B. Lead it be! Identifying the construction phases of gothic cathedrals using lead analysis by LA-ICP-MS. J. Archaeol. Sci. Rep. 2016, 6, 252-265. [CrossRef]

Publisher's Note: MDPI stays neutral with regard to jurisdictional claims in published maps and institutional affiliations.

(C) 2020 by the authors. Licensee MDPI, Basel, Switzerland. This article is an open access article distributed under the terms and conditions of the Creative Commons Attribution (CC BY) license (http://creativecommons.org/licenses/by/4.0/). 